Behavioral/Cognitive

\title{
Nicotinic $\alpha 4 \beta 2$ Cholinergic Receptor Influences on Dorsolateral Prefrontal Cortical Neuronal Firing during a Working Memory Task
}

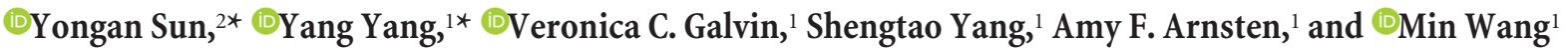 \\ ${ }^{1}$ Department of Neuroscience, Yale University School of Medicine, New Haven, Connecticut 06510, and ${ }^{2}$ Department of Neurology, Peking University First \\ Hospital, Beijing 100034
}

\begin{abstract}
The primate dorsolateral prefrontal cortex (dIPFC) subserves top-down regulation of attention and working memory abilities. Depletion studies show that the neuromodulator acetylcholine (ACh) is essential to dIPFC working memory functions, but the receptor and cellular bases for cholinergic actions are just beginning to be understood. The current study found that nicotinic receptors comprised of $\alpha 4$ and $\beta 2$ subunits $(\alpha 4 \beta 2$-nAChR) enhance the task-related firing of delay and fixation cells in the dlPFC of monkeys performing a working memory task. Iontophoresis of $\alpha 4 \beta 2$-nAChR agonists increased the neuronal firing and enhanced the spatial tuning of delay cells, neurons that represent visual space in the absence of sensory stimulation. These enhancing effects were reversed by coapplication of a $\alpha 4 \beta 2$-nAChR antagonist, consistent with actions at $\alpha 4 \beta 2$-nAChR. Delay cell firing was reduced when distractors were presented during the delay epoch, whereas stimulation of $\alpha 4 \beta 2$-nAChR protected delay cells from these deleterious effects. Iontophoresis of $\alpha 4 \beta 2$-nAChR agonists also enhanced the firing of fixation cells, neurons that increase firing when the monkey initiates a trial, and maintain firing until the trial is completed. These neurons are thought to contribute to sustained attention and top-down motor control and have never before been the subject of pharmacological inquiry. These findings begin to build a picture of the cellular actions underlying the beneficial effects of ACh on attention and working memory. The data may also help to explain why genetic insults to $\alpha 4$ subunits are associated with working memory and attentional deficits and why $\alpha 4 \beta 2$-nAChR agonists may have therapeutic potential.
\end{abstract}

Key words: in vivo single-cell recording; iontophoresis; nicotinic alpha4beta2 receptor; nonhuman primate; prefrontal cortex; working memory

\section{Significance Statement}

The acetylcholine (ACh) arousal system in the brain is needed for robust attention and working memory functions, but the receptor and cellular bases for its beneficial effects are poorly understood in the newly evolved primate brain. The current study found that ACh stimulation of nicotinic receptors comprised of $\alpha 4$ and $\beta 2$ subunits ( $\alpha 4 \beta 2$-nAChR) enhanced the firing of neurons in the primate prefrontal cortex that subserve top-down attentional control and working memory. $\alpha 4 \beta 2$-nAChR stimulation also protected neuronal responding from the detrimental effects of distracters presented during the delay epoch, when information is held in working memory. These results illuminate how ACh strengthens higher cognition and help to explain why genetic insults to the $\alpha 4$ subunit weaken cognitive and attentional abilities.

\section{Introduction}

Acetylcholine (Ach) has been known to have important influences on working memory and attentional abilities for decades

Received Feb. 8, 2017; revised March 31, 2017; accepted April 24, 2017.

Author contributions: Y.S., Y.Y., A.F.A., and M.W. designed research; Y.S., Y.Y., and M.W. performed research; Y.S., Y.Y., V.C.G., S.Y., and M.W. analyzed data; Y.S., Y.Y., V.C.G., S.Y., A.F.A., and M.W. wrote the paper.

This work was supported by National Institutes of Health (Grant R01 MH093354), the Alzheimer's Association (M.W.), and the Ellison American Federation for Aging Research (Postdoctoral Fellowship to Y.Y.). We thank L. Ciavarella, S. Johnson, T. Sadlon, M. Wilson, and M. Horn for invaluable technical support.

The authors declare no competing financial interests.

Y. Yang's present address: Department of Neurology, Pennsylvania State University College of Medicine, Hershey, PA 17033.
(Bartus and Johnson, 1976; Granon et al., 1995; Sarter et al., 1997; Levin et al., 2006; Mansvelder et al., 2009), but the specific receptor and molecular mechanisms underlying its various roles in cognitive function have only begun to be understood. Ach acts at a variety of metabotropic muscarinic and ionotropic nicotinic receptor subtypes, the latter comprised of five $\alpha(\alpha 2-\alpha 10)$ and/or

*Y.S. and Y.Y. contributed equally to this work.

Correspondence should be addressed to Min Wang, Ph.D., Department of Neuroscience, Yale University School of Medicine, 333 Cedar Street, New Haven, CT 06510. E-mail: min.wang@yale.edu.

DOI:10.1523/JNEUROSCI.0364-17.2017

Copyright $\odot 2017$ the authors $\quad 0270-6474 / 17 / 375366-12 \$ 15.00 / 0$ 
$\beta$ ( $\beta 2-\beta 4$ ) subunits. The $\alpha 4 \beta 2$ nicotinic receptor ( $\alpha 4 \beta 2$-nAChR) is of interest given its high affinity for nicotine and its relationship to cigarette smoking (Picciotto and Kenny, 2013; McClureBegley et al., 2016), its widespread distribution in brain (Han et al., 2000), and its links to cognitive processing. For example, genetic alterations in the $\alpha 4$ subunit in humans have been associated with altered cognitive and attentional abilities (Reinvang et al., 2009; Espeseth et al., 2010; Mobascher et al., 2016) and possibly to greater incidence of attention deficit hyperactivity disorder (ADHD) (Kent et al., 2001; Winterer et al., 2007; Wallis et al., 2009). Similarly, genetic knockdown or blockade of nicotinic $\alpha 4$ and/or $\beta 2$ nicotinic subunits impairs, whereas stimulation improves, attentional processing in rodent models (Guillem et al., 2011; Bloem et al., 2014; Wood et al., 2016) and stimulation of the cholinergic basal forebrain can enhance visual processing in the visual cortex through muscarinic receptors (Goard and Dan, 2009). Research in monkeys has also shown prominent muscarinic effects on attentional enhancement of visual processing in V1 (Herrero et al., 2008), but only limited influences of nicotinic receptor stimulation (Disney et al., 2007). However, systemic administration of the $\alpha 4 \beta 2$-nAChR agonist ABT-418 to monkeys improved working memory performance under distracting conditions (Prendergast et al., 1998), suggesting that these receptors may have beneficial effects in primate cortex in more anterior cortical regions.

The dorsolateral prefrontal cortex (dlPFC) plays a fundamental role in working memory and attentional processing. Lesions to the dlPFC in monkeys impair top-down attentional control (Rossi et al., 2007) and produce profound deficits in working memory, particularly when distractors are presented during the delay period (Grueninger and Pribram, 1969; Bartus and Levere, 1977). More recent physiology studies have provided a cellular basis for this phenomenon, finding that dIPFC neurons are uniquely capable of maintaining firing to a relevant stimulus and suppressing responses to distractors (Miller et al., 1996; Suzuki and Gottlieb, 2013). dlPFC neurons also fire in relationship to top-down attentional control, whereas bottom-up attention emanates from more posterior cortices (Buschman and Miller, 2007). The cognitive functioning of the dlPFC is remarkably dependent on modulatory influences by ACh because ACh depletion from dlPFC produces working memory deficits comparable to dlPFC ablation (Croxson et al., 2011). This can also be seen at the cellular level, where cholinergic stimulation of nicotinic $\alpha 7$ receptors ( $\alpha 7$-nAChRs) has a critical, permissive effect on dlPFC NMDA receptor (NMDAR) actions needed for neuronal firing during a working memory task (Yang et al., 2013). However, there have been no studies examining how $\alpha 4 \beta 2$-nAChRs influence the firing patterns of dlPFC neurons.

The current study examined the roles of $\alpha 4 \beta 2$-nAChR stimulation on dIPFC neuronal firing in monkeys performing an oculomotor delayed response (ODR) task, a test of visuospatial working memory (Fig. 1A), while recording single units from the dIPFC (Fig. $1 D)$. In addition, we tested the role of $\alpha 4 \beta 2$-nAChR under distracting conditions, when irrelevant stimuli were presented during the delay period (Fig. 1B). The dIPFC contains a variety of working memory task-related neurons (Funahashi et al., 1991), including fixation cells that sustain firing across each trial, neurons that fire in relationship to the sensory cue (cue cells), or to the saccadic response (response cells), as well as delay cells, which maintain firing across the delay epoch in a spatially tuned manner with greater firing for their "preferred direction" (Fig. 1E). Delay cells are thought to carry the neuronal representations needed to maintain goals in working memory and to protect these goals from the interference of distraction (Goldman-Rakic, 1995) (Goldman-Rakic, 1995); therefore, these cells were the focus of the current study. We also examined drug effects on fixation cells, given their potential role in sustained attention, as well as task-related cue and response cells for comparison. We found that $\alpha 4 \beta 2-\mathrm{nAChR}$ stimulation enhanced the firing of delay cells and fixation cells and protected delay cell firing from the detrimental effects of distraction.

\section{Materials and Methods}

Subjects. Three adult male rhesus monkeys (Macaca mulatta) were used for the current study and were cared for under the guidelines of the National Institutes of Health and the Yale University Institutional Animal Care and Use Committee.

ODR task. The monkeys were seated in primate chairs with their heads fixed and faced a 27 inch computer monitor 30 inches in front of them. The monkeys' eye positions were monitored with the ISCAN eye movement monitoring system. The monkeys were trained in the visuospatial ODR task, which required the subject to make a memory-guided saccade to a remembered visuospatial target. Patients with schizophrenia have been shown to be impaired on a human version of this task (Keedy et al., 2006). The ODR task was generated by the PICTO system (customdesigned Windows-based data acquisition software). The task is illustrated in Figure 1A. A central small white circle was illuminated on the computer monitor, which served as the fixation target. To initiate a trial, the animal fixated this central target and maintained fixation for $0.5 \mathrm{~s}$ (fixation period), whereupon a cue (the same sized white circle) was illuminated for a period of $0.5 \mathrm{~s}$ (cue period) at 1 of 8 peripheral targets located at an eccentricity of $13^{\circ}$ with respect to the fixation spot. After the cue was extinguished, a $2.5 \mathrm{~s}$ delay period followed. The subject was required to maintain central fixation throughout both the cue presentation and the delay period. At the end of the delay, the fixation spot was extinguished, which instructed the monkey to make a memory-guided saccade to the location where the cue had been shown before the delay period. A trial was considered successful if the subject's response was completed within $0.5 \mathrm{~s}$ of the offset of the fixation spot and was within $2^{\circ}$ around the correct cue location. The subject was rewarded with fruit juice immediately after every successful response. The position of the stimulus was randomized over trials such that it had to be remembered on a trial-by-trial basis. The intertrial intervals (ITIs) were at least $3 \mathrm{~s}$. The subject performed 1000-1500 trials per session.

ODR task with distractors. During distractor trials, a red distracter $(0.5$ s duration) was presented during the delay period, as shown in Figure $1 B$. Because the cue was a white circle, the red color of the distractor indicated that the stimulus was irrelevant. The distracter occurred randomly at 1 of 3 locations opposite to the cue $1 \mathrm{~s}$ after the delay period was initiated. Distractors were only tested during recordings from delay cells.

Recording locus. Before recording, the animals underwent an MRI scan to obtain exact anatomical coordinates of brain structures, which guided placement of the chronic recording chambers. MRI-compatible materials were used for the implant so that another MRI could be performed after implantation to confirm the position of the recording chambers. The recording wells were placed over the caudal principal sulcus as illustrated in Figure $1 D$.

In vivo single-unit recordings and iontophoresis. This study used iontophoresis to apply the $\alpha 4 \beta 2$-nAChR agonists ABT-418 and RJR2403 and/or the $\alpha 4 \beta 2$-nAChR antagonist $\mathrm{DH} \beta \mathrm{E}$ near dlPFC neurons. ABT418 was from Sigma-Aldrich. $\mathrm{DH} \beta \mathrm{E}$ and RJR2403 were from Tocris Bioscience. Drug solutions (5-10 mM, pH 3-4) were made using sterilized water. Iontophoretic electrodes were constructed with a $20 \mu \mathrm{m}$ pitch carbon fiber (ELSI) inserted in the central barrel of a seven-barrel nonfilamented capillary glass (Friedrich and Dimmock). The assembly was pulled using a multipipette electrode puller (PMP-107L; MicroData Instrument) and the tip was beveled to obtain the finished electrode (Fig. $1 C)$. Finished electrodes had impedances of $0.3-1.5 \mathrm{M} \Omega($ at $1 \mathrm{kHz})$ and tip sizes of 30-40 $\mu \mathrm{m}$. The outer barrels of the electrode were then filled with three drug solutions (two consecutive barrels each) and the solutions were pushed to the tip of the electrode using compressed air. A Neurophore $\mathrm{BH} 2$ iontophoretic system (Medical Systems) was used to control the delivery of the drugs. The drug was ejected at currents that 
A

C
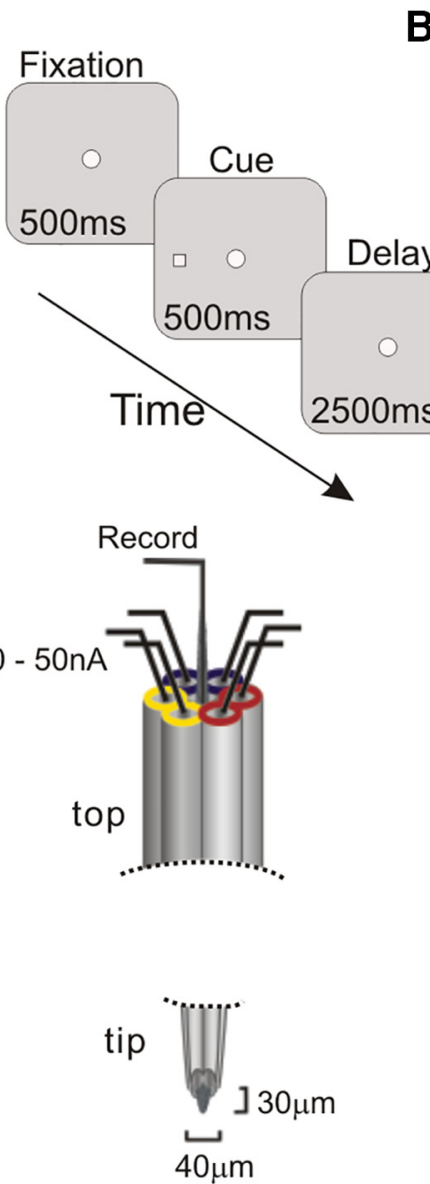

E
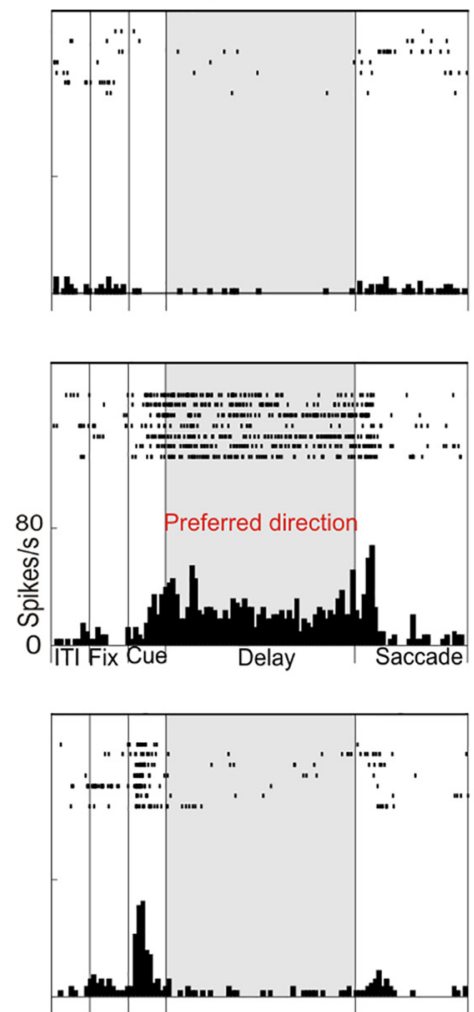

B Fixation

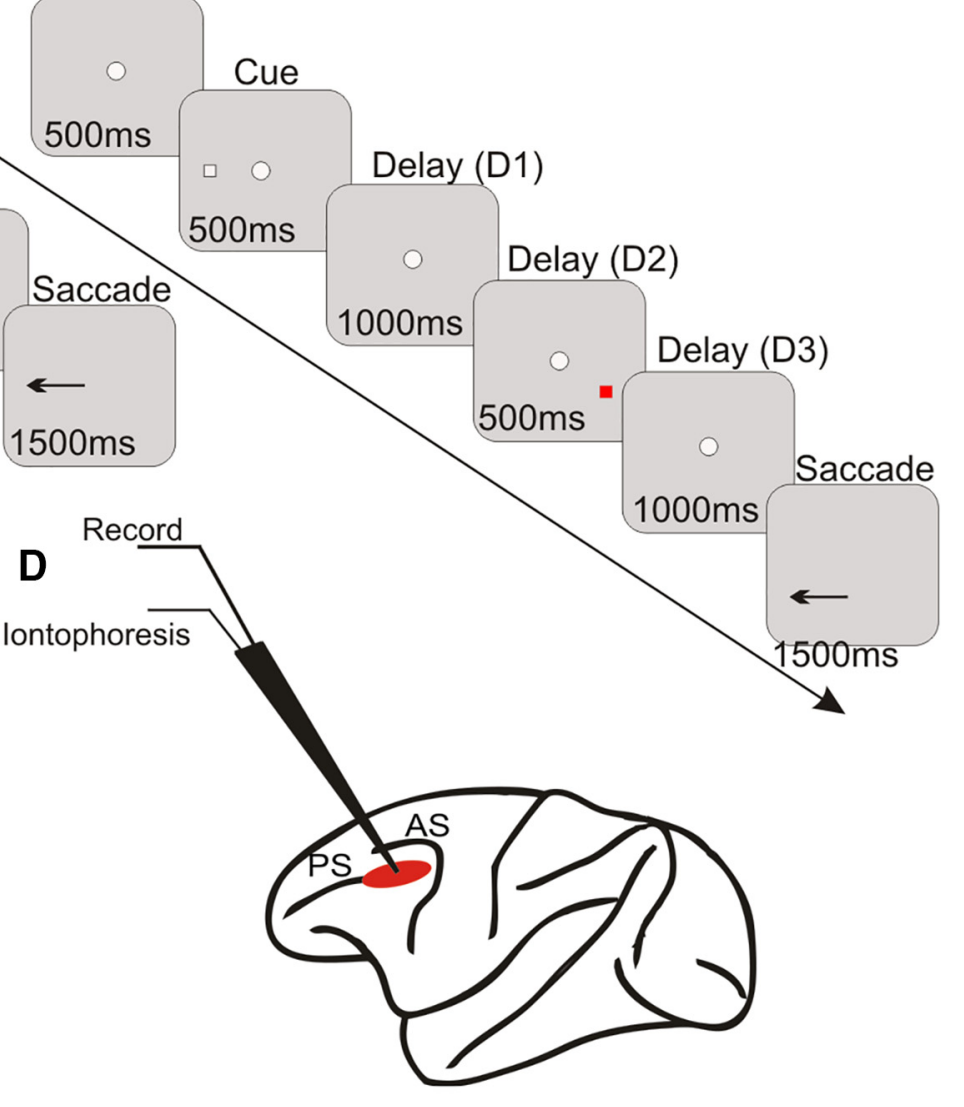

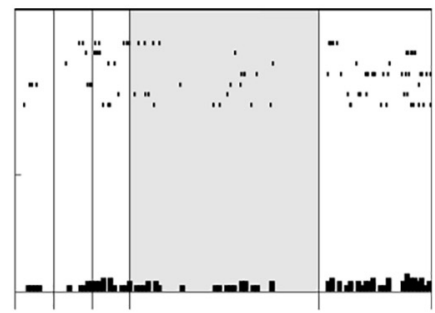
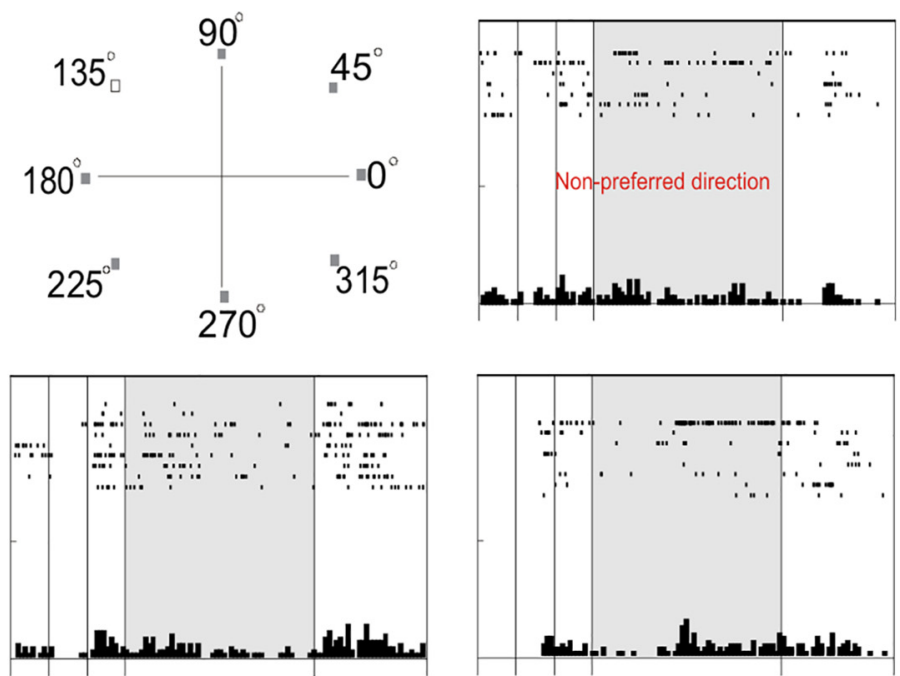

Figure 1. Paradigm used for iontophoretic recordings in monkeys performing a spatial working memory task. $\boldsymbol{A}$, ODR spatial working memory task. $\boldsymbol{B}$, Distractor version of the 0DR task. C, Schematic of the iontophoresis/recording electrode with six micropipettes surrounding the carbon fiber electrode, where different compounds can be delivered by currents through different pipettes; for example, drug 1 (in two consecutive yellow pipettes) versus drug 2 (in two red pipettes). $D$, Region of the caudal principal sulcal (PS) PFC, where recordings are performed. AS, Arcuate sulcus. $\boldsymbol{E}$, Typical dIPFC delay cell with spatially tuned, delay-related firing. Rasters and histograms are arranged to indicate the location of the corresponding cue; the preferred direction for this neuron was $180^{\circ}$. Please note that, in subsequent figures, only the preferred direction and one nonpreferred direction will be shown for neurons with delay-related firing to conserve space. 
varied from 10 to $25 \mathrm{nA}$. Retaining currents of -5 to $-10 \mathrm{nA}$ were used in a cycled manner ( $1 \mathrm{~s}$ on, $1 \mathrm{~s}$ off) when not applying drugs. Drug ejection did not create noise in the recording and there was no systematic change in either spike amplitude or time course at any ejection current.

The electrode was mounted on a MO-95 micromanipulator (Narishige) in a 25-gauge stainless steel guide tube. The dura was then punctured using the guide tube to facilitate access of the electrode to cortex. Extracellular voltage was amplified using an AC/DC differential preamplifier (Model 3000; A-M Systems) and band-pass filtered $(180 \mathrm{~Hz}-6 \mathrm{kHz}$, $20 \mathrm{~dB}$ gain, 4-pole Butterworth; Kron-Hite). Signals were digitized (15 $\mathrm{kHz}$, micro 1401; CED) and acquired using Spike2 software (CED). Neural activity was analyzed using waveform sorting by a template-matching algorithm. Poststimulus time histograms (PSTHs) and rastergrams were constructed online to determine the relationship of unit activity to the task. Unit activity was measured in spikes per second. Four different kinds of ODR task-related cells were classified: fixation cells, cue cells, delay cells, and response cells. If the rastergrams showed that a neuron displayed task-related activity, then recording continued and pharmacological testing was performed. A total of 101 task-related cells were recorded and tested with $\alpha 4 \beta 2-\mathrm{nAChR}$ agents (72 from Monkey C, 24 from Monkey A, and 5 from Monkey P). The percentages of task-related neurons were as follows: fixation cells 22 (22\%), delay cells 43 (43\%), cue cells $6(6 \%)$, and response cells $30(30 \%)$.

Neuronal activities were first collected from the cell under a control condition in which at least eight trials at each of eight cue locations was obtained. Upon establishing the stability of the cells' activity, this control condition was followed by iontophoretic application of $\operatorname{drug}(\mathrm{s})$. Dosedependent effects of the drug were tested in two or more consecutive conditions, which was followed by a recovery condition or a reversal condition. Drugs were applied continuously at a relevant current throughout a given condition. Each condition had $\sim 8$ (range 6-12) trials at each location to allow for statistical analyses of drug effects. In the distractor experiments, neuronal firing was first recorded under control classic ODR condition (no distraction). If the cell showed spatially tuned delayrelated activity from the online PSTHs and rastergrams, then the control condition was followed by ODR with distractor condition and then by iontophoretic application of the $\alpha 4 \beta 2-\mathrm{nAChR}$ agonist condition as the monkey performed the distractor version of the task.

Data analysis. For purposes of data analysis, each trial in the ODR task was divided into four epochs - initial fixation, cue, delay, and response (saccade). The initial fixation epoch lasted for $0.5 \mathrm{~s}$. The cue epoch lasted for $0.5 \mathrm{~s}$ and corresponds to the stimulus presentation phase of the task. The delay lasted for $2.5 \mathrm{~s}$ and reflects the mnemonic component of the task. The response phase started immediately after the delay epoch and lasted $\sim 1.5 \mathrm{~s}$. Data analysis was performed in MATLAB and SPSS. Spike density functions were constructed in $50 \mathrm{~ms}$ windows. Two-way ANOVA was used to examine the spatially tuned task-related activity with regard to different periods of the task (fixation, cue, delay, and response vs ITI) and different cue locations. This study mainly focused on delay cells that represent working memory. Many delay cells fire during the cue and/or response epochs as well as the delay epoch; given their variable responding to the cue and response epochs, data analyses focused on the delay epoch. One-way ANOVA or two-tailed paired $t$ test were used to assess the effects of drug application on task-related activity. In the interest of brevity, figures often show the neurons' preferred direction compared with just one nonpreferred direction, the "antipreferred" direction directly opposed to the neurons' preferred direction. For delay cells, spatial tuning was assessed by comparing firing levels for the neuron's preferred direction vs its nonpreferred directions. Quantification of spatial tuning was performed by calculating a measure of $d^{\prime}$ using the following formula:

$$
d^{\prime}=\left(\text { mean }_{\text {pref }}-\text { mean }_{\text {nonpref }}\right) / \sqrt{\left(s d_{\text {pref }}^{2}+s d_{\text {nonpref }}^{2}\right) / 2}
$$

\section{Results}

The results of iontophoresing $\alpha 4 \beta 2$-nAChR compounds on taskrelated neurons in the primate $\mathrm{dlPFC}$ are summarized below. Please note that the iontophoresis procedure itself has no effect on neuronal firing on its own; that is, iontophoresis of vehicle (saline, $\mathrm{pH}$ 4) with either a positive or negative current has no effect on neuronal firing (Vijayraghavan et al., 2007). In addition, iontophoresis releases very small amounts of drug, which likely influence a mini-column of nearby neurons, but are inadequate to influence behavioral performance. Behavioral performance was maintained at optimal levels unless otherwise noted, that is, during conditions of distraction.

\section{Stimulation of $\alpha 4 \beta 2-n A C h R$ enhances the delay-related firing and spatial tuning of dlPFC delay cells}

We first tested the effect of $\alpha 4 \beta 2$-nAChR agonists on the delayrelated $(0-2.5 \mathrm{~s})$ firing and spatial tuning of dlPFC delay cells in monkeys performing the classic ODR task (Fig. $1 A$ ). We found that iontophoresis of $\alpha 4 \beta 2$-nAChR agonists significantly enhanced the delay-related firing and spatial tuning of delay cells. As seen in a single-cell example in Figure $2 A$, iontophoretic application of the $\alpha 4 \beta 2$-nAChR agonist ABT- 418 produced a doserelated enhancement in delay-related firing for the neuron's preferred direction, but not for its nonpreferred direction. Similarly, in another single-cell example shown in Figure $2 B$, iontophoretic application of another $\alpha 4 \beta 2-\mathrm{nAChR}$ agonist, RJR2403, enhanced delay-related firing and firing returned to control levels when the drug was no longer applied (Fig. $2 B$, recovery condition, light blue line). The enhancing effects of $\alpha 4 \beta 2-\mathrm{nAChR}$ agonists were consistent in all 25 delay cells recorded. Figure $2 C$ shows the averaged effect of $\alpha 4 \beta 2-\mathrm{nAChR}$ agonist on delay cell firing at the population level, where $\alpha 4 \beta 2-\mathrm{nAChR}$ agonist at doses of 10-25 nA significantly enhanced delay cell firing during the delay period for the neurons' preferred directions. Given the similarities between the two agonists, these averaged data include neurons administered either ABT-418 or RJR2403. Statistical analysis showed that $\alpha 4 \beta 2-\mathrm{nAChR}$ agonist application significantly increased neuronal firing during the delay epoch for the neurons' preferred direction $\left(t_{\mathrm{dep}(24)}=10.49, p<0.0001\right.$, twotailed paired $t$ test; Fig. $2 D$ ), but not for the nonpreferred direction $\left(t_{\mathrm{dep}(24)}=1.948, p=0.063\right.$, two-tailed paired $t$ test; Fig. $\left.2 D\right)$. Because this enhancement in delay-related firing by $\alpha 4 \beta 2$ $\mathrm{nAChR}$ agonists is direction selective, we investigated whether $\alpha 4 \beta 2$-nAChR agonists also enhance the spatial tuning of delay cells as assessed by $d^{\prime}$ (see formula in Materials and Methods). This measure captures how well a delay cell can represent a spatial position over the delay epoch in the absence of sensory stimulation, and thus is particularly important to the strength of working memory. Figure $2 E$ shows a scatter plot of $d^{\prime}$ values comparing each neuron's firing for its preferred versus nonpreferred directions to illustrate a neuron's spatial tuning under control versus $\alpha 4 \beta 2$-nAChR agonist conditions. A greater $d^{\prime}$ value indicates greater directional selectivity; that is, greater spatial tuning. A total of 20-25 delay cells showed higher $d^{\prime}$ in the $\alpha 4 \beta 2-\mathrm{nAChR}$ agonist condition compared with the control condition. Overall, iontophoresis of $\alpha 4 \beta 2-\mathrm{nAChR}$ agonists significantly enhanced the spatial tuning of delay cell firing during the delay epoch by increasing $d^{\prime} t_{\mathrm{dep}(24)}=3.712, p=0.001$, two-tailed paired $t$ test; Fig. 2F)

In addition to enhancing cell firing during the delay epoch, $\alpha 4 \beta 2-\mathrm{nAChR}$ agonists produced a small but significant increase in firing during the initial fixation period $(-1$ to $-0.5 \mathrm{~s})$. This small increase in firing was evident for both the preferred and nonpreferred directions (preferred: $t_{\mathrm{dep}(24)}=2.25, p=0.033$; nonpreferred: $t_{\mathrm{dep}(24)}=2.38, p=0.02$, two-tailed paired $t$ test; Fig. $2 C, D)$. Because the cue had yet to occur during this epoch, it is not surprising that drug-induced increases in delay cell firing during the initial fixation period were not direction selective. 
A
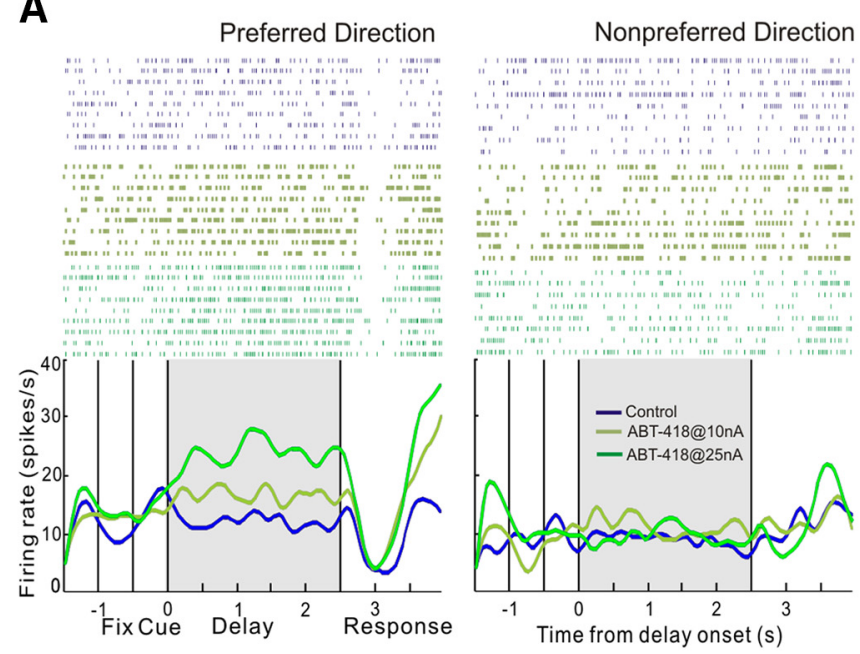

\section{C}
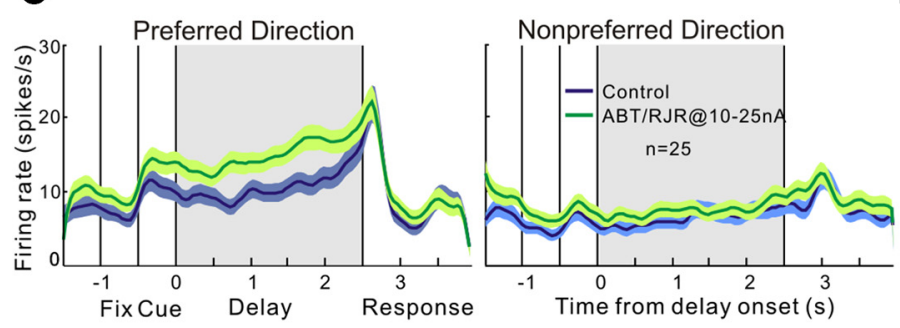

E

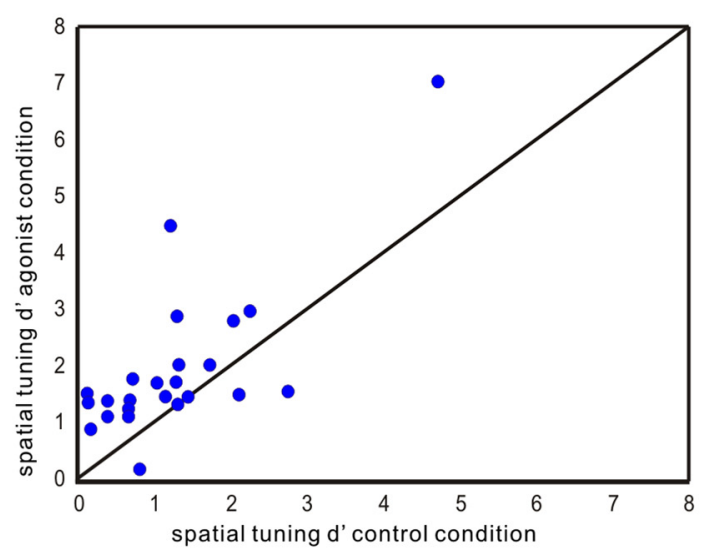

B
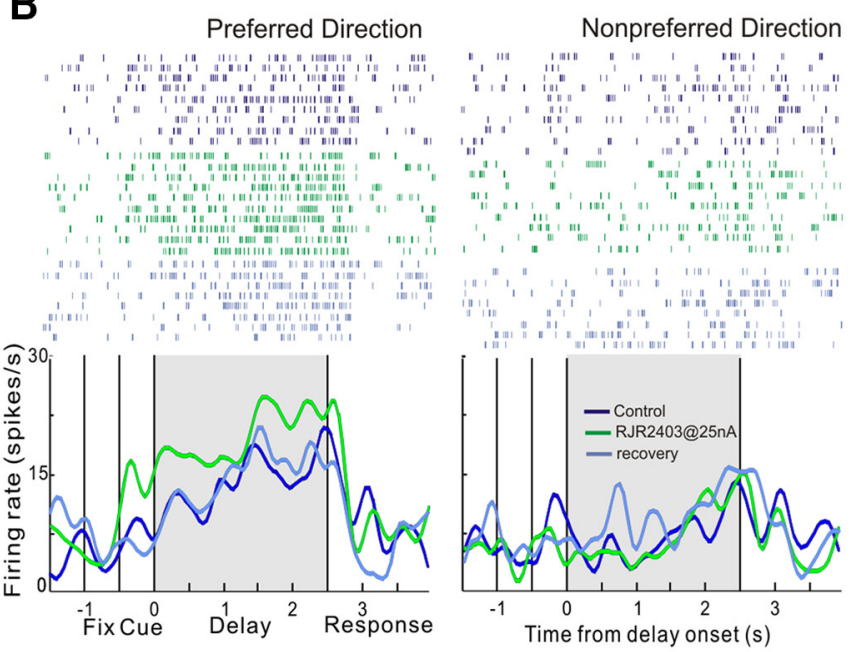

D

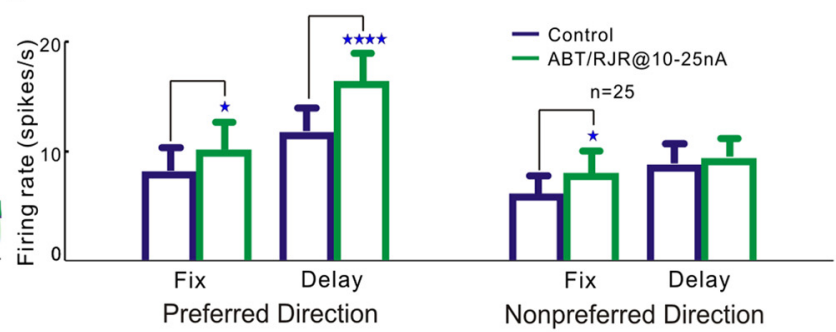

$\mathbf{F}$

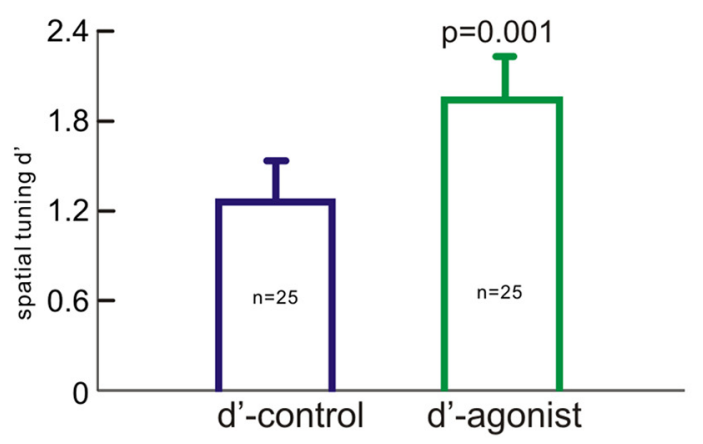

Figure 2. Effects of $\alpha 4 \beta 2$-nAChR agonists on the task-related firing of dIPFC delay cells. $A$, Single-neuron example of the dose-dependent effects of the $\alpha 4 \beta 2$-nAChR agonist ABT-418 on delay-related activity. The top part of the figure shows spike raster plots for the neuron's preferred versus nonpreferred direction. The bottom part of the figure shows the spike density function of this neuron. Data are shown for three different conditions: control conditions (blue), ABT-418 at $10 \mathrm{nA}$ (Martian green) and ABT-418 at $25 \mathrm{nA}$ (green). ABT-418 produced a dose-dependent increase in delay-related firing selectively for the neuron's preferred direction. $B$, Single-neuron example of the enhancing effects of another $\alpha 4 \beta 2$-nAChR agonist, RJR2403. Iontophoresis of RJR2403 at 25 $\mathrm{nA}$ significantly enhanced delay-related firing for the neuron's preferred direction, but not for the nonpreferred direction (green). Activity was reduced to control levels after drug application was terminated during the recovery condition (light blue). C, Population spike density functions for the average of 25 delay cells showing firing for their preferred versus their nonpreferred directions under control conditions (blue) and after iontophoresis of an $\alpha 4 \beta 2$-nAChR agonist (green). $D$, Mean \pm SEM firing rate of these same 25 delay cells during the initial fixation versus delay epochs of the task. Statistical analysis shows that $\alpha 4 \beta 2$ agonist significantly enhance the delay firing for the preferred direction, but not for the nonpreferred direction, whereas the $\alpha 4 \beta 2$-nAChR agonist slightly but significantly enhanced the fixation period firing for both the preferred and the nonpreferred direction. $E$, Scatter plot of $d^{\prime}$ comparing each neuron's firing of delay period for its preferred versus nonpreferred directions to examine the neuron's spatial tuning. Greater $d^{\prime}$ value indicates greater directional selectivity. $\boldsymbol{F}$, Iontophoresis of $\alpha 4 \beta 2$-nAChR agonists significantly enhanced the spatial tuning of delay cell by increasing $d^{\prime}$. Error bars indicate SEM. ${ }^{*} p<0.05 ;{ }^{* *} p<0.01 ;{ }^{* * *} p<0.0001$.

We next tested whether the enhancing effects of ABT-418 occurred at $\alpha 4 \beta 2$-nAChR by determining whether coapplication of the $\alpha 4 \beta 2$-nAChR antagonist $\mathrm{Dh} \beta \mathrm{E}$ would block the enhancing effects of ABT-418. We found that co-iontophoresis of DH $\beta \mathrm{E}$ reversed the enhancing effects of ABT-418 on delay-related firing of delay cells. As shown in Figure 3, $A$ and B, ABT-418 at $25 \mathrm{nA}$ significantly increased delay-related firing for the neurons' preferred direction and these enhancing effects of ABT-418 were reversed by co-iontophoresis of $\mathrm{DH} \beta \mathrm{E}$ (overall: $\chi^{2} / \mathrm{df}=9.3 / 2$, $p=0.009$, Friedman test; pairwise comparisons: control vs ABT418: $\mathrm{S}=-10.5, p=0.03$; control vs ABT418+DH $\beta \mathrm{E}: \mathrm{S}=$ $-1.5, p=0.84$; ABT418 vs ABT418+DH $\beta$ E: $\mathrm{S}=-10.5, p=$ 0.03 , Wilcoxon signed-rank test; Fig. $3 B$ ). These results are consistent with ABT-418 acting at $\alpha 4 \beta 2$-nAChR.

We also found that the converse was true: co-iontophoresis of RJR2403 could reverse the reduction in delay-related firing in- 
A

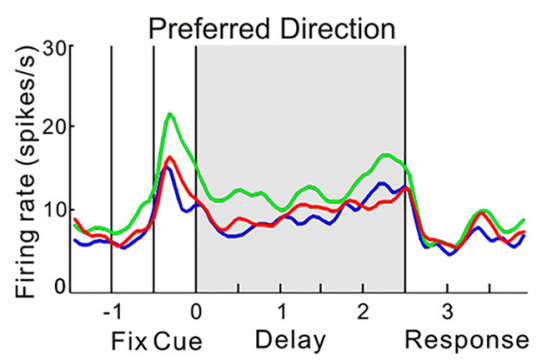

Nonpreferred Direction

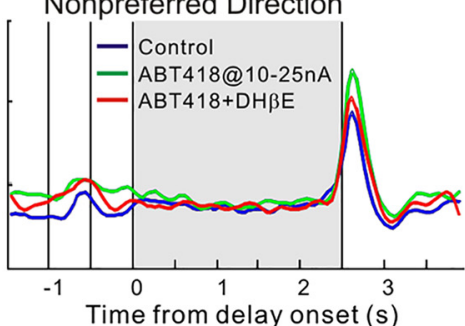

B

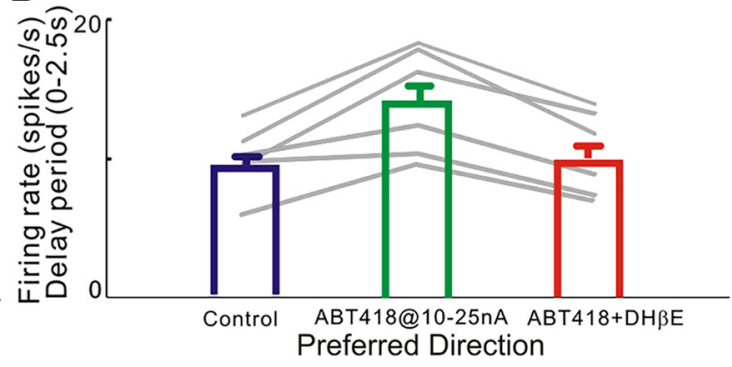

C

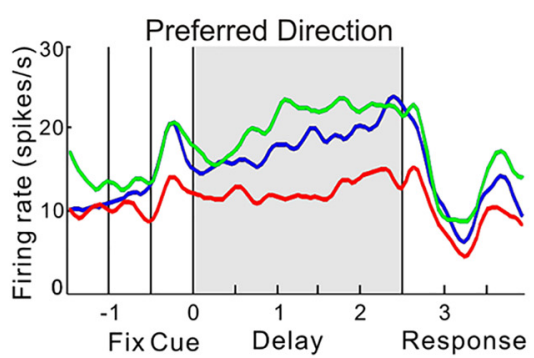

Nonpreferred Direction

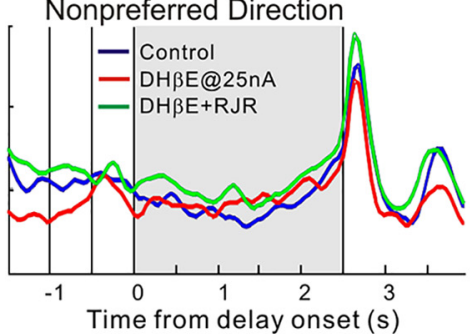

D

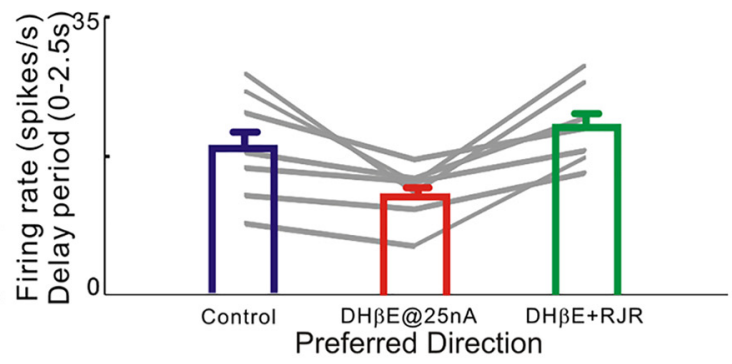

Figure 3. $\alpha 4 \beta 2$-nAChR agonist versus antagonist reverse each other's actions. $\boldsymbol{A}, \boldsymbol{B}, \mathrm{An} \alpha 4 \beta 2$-nAChR antagonist reversed the enhancing actions of an $\alpha 4 \beta 2$-nAChR agonist. $\boldsymbol{A}$, The $\alpha 4 \beta 2$ $\mathrm{nAChR}$ agonist ABT-418 significantly increased delay-related firing (green) and the enhancement was reversed by co-ionotophoresis of the $\alpha 4 \beta 2$-nAChRantagonist DH $\beta$ E at $15 \mathrm{nA}$ (red), consistent with ABT-418 actions on $\alpha 4 \beta 2$-nAChR. $B$, Mean \pm SEM firing rate (delay period of preferred direction) of six delay cells and a scatter plot of delay-related firing of each neuron showing that $\mathrm{DH} \beta \mathrm{E}+\mathrm{ABT}-418$ reversed the enhancement of ABT-418. C, D, $\alpha 4 \beta 2$-nAChR agonist reversed the reduction in firing induced by an $\alpha 4 \beta 2$-nAChR antagonist. $\boldsymbol{C}, \alpha 4 \beta 2$-nAChR antagonist DH $\beta \mathrm{E}$ significantly decreased delay-related firing (red) and the reduction was reversed by co-ionotophoresis of the $\alpha 4 \beta 2$-nAChR agonist ABT-418. $D$, Mean \pm SEM firing rate (delay period of preferred direction) of seven delay cells and a scatter plot of delay-related firing of each neuron showing that ABT-418+DH $\beta$ E reversed the reduction of DH $\beta E$.

duced by the $\alpha 4 \beta 2-\mathrm{nAChR}$ antagonist, $\mathrm{DH} \beta \mathrm{E}$. As shown in Figure $3, C$ and $D, D H \beta E$ at $25 \mathrm{nA}$ significantly reduced delayrelated firing for the neurons' preferred direction and these reductions were then reversed by co-iontophoresis of RJR2403 (overall: $\chi^{2} / \mathrm{df}=11.1 / 2, p=0.004$, Friedman test; pairwise comparisons: control vs $\mathrm{DH} \beta \mathrm{E}: \mathrm{S}=14, p=0.016$; control vs DH $\beta E+R J R 2403: S=-11, p=0.078 ; D H \beta E+R J R 2403$ vs $\mathrm{DH} \beta \mathrm{E}: \mathrm{S}=14, p=0.016$, Wilcoxon signed-rank test; Fig. $3 D$ ). Therefore, the $\alpha 4 \beta 2$-nAChR agonist versus antagonist had opposing, competitive effects on delay cell firing.

\section{Presentation of distractors impairs working memory performance and interrupts dlPFC delay cell firing}

To further test the effects of $\alpha 4 \beta 2$-nAChR agonists under attention-demanding conditions, we modified the ODR task by adding a distractor on each trial during the delay period. The modified version of the ODR task is shown in Figure $1 B$. Assessment of behavioral performance showed that the presentation of a distractor during the delay epoch significantly impaired the accuracy of spatial working memory performance. As shown in Figure $4 A$, the average percentage correct for 18 test sessions with classic ODR trials was $90 \%$, whereas the average percentage correct for 18 test sessions with distractor trials was only $75 \%\left(t_{\mathrm{dep}(33)}=\right.$ 6.624, $p<0.001, n=18$ sessions, two-tailed $t$ test).

At the neuronal level, the presentation of a distractor also altered delay cell firing during the delay period. As shown in Figure $4 B$, a single-cell example, and Figure $4 C$, a population analysis, under control conditions without distraction (blue), the neuron showed strong persistent firing throughout the delay epoch for its preferred direction and little firing for its nonpreferred direction. The presentation of a distractor (red) during the delay period from 1.0-1.5 s (indicated by pink shading) reduced the delay-related firing for the neuron's preferred direction, specifically reducing the firing in the later delay period (1.0-2.5 s, during and after the distractor presentation; $t_{\mathrm{dep}(17)}=3.564, p=0.002$, two-tailed paired $t$ test). In contrast, the presentation of a distractor produced a transient activation during the 1.0-1.5 s epoch of the delay period for the neuron's nonpreferred direction $\left(t_{\mathrm{dep}(17)}=\right.$ 3.077, $p=0.006$, two-tailed paired $t$ test). Therefore, the presentation of the distractor reduced the spatial tuning of delay cells, especially for the latter portion of the delay epoch 1.0-2.5 s. A total of 16 of 18 delay cells showed reduced $d^{\prime}$ in the ODRdistractor condition compared with the control ODR condition (Fig. 4D) and the reduction of spatial tuning was highly significant $\left(t_{\mathrm{dep}(17)}=4.258, p=0.0005\right.$, two-tailed paired $t$ test; Fig. $\left.4 E\right)$ due to both decreasing the firing for the neurons' preferred direction and increasing the firing for the nonpreferred direction. Therefore, the presentation of a distractor during the delay epoch weakened delay representations of visual space.

\section{Stimulation of $\alpha 4 \beta 2-n A C h R$ restores delay-related firing during distracting conditions in dlPFC delay cells}

The effects of $\alpha 4 \beta 2-\mathrm{nAChR}$ stimulation on delay cell firing were next investigated during distracting conditions to determine whether they could rescue neuronal firing patterns. As seen in a single-cell example in Figure $5 A$, iontophoresis of the $\alpha 4 \beta 2$ nAChR agonist RJR2403 (green) restored the loss of firing for the neuron's preferred direction caused by the presentation of a distractor. This rescue of firing for a neuron's preferred direction could be seen for the population of delay cells $(n=10$; Fig. $5 B)$ and was statistically significant compared with distraction in the absence of the $\alpha 4 \beta 2$-nAChR agonist (distractor vs distractor+RJR2403 condition: $t_{\mathrm{dep}(9)}=3.212, p=0.01$, two-tailed paired $t$ test). However, the distraction-induced firing for the neurons' nonpre- 
A

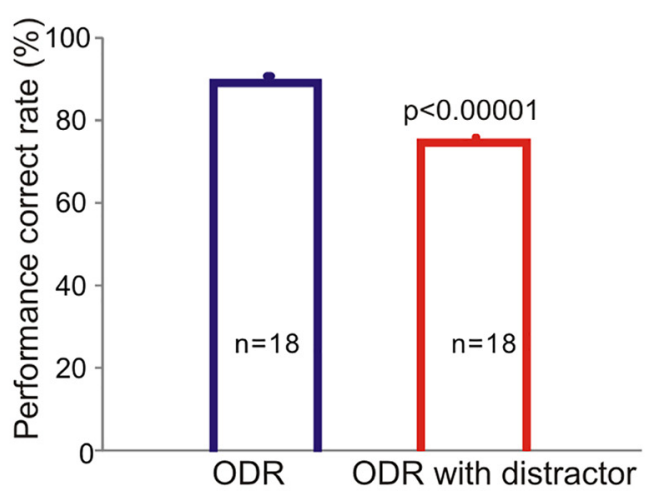

B
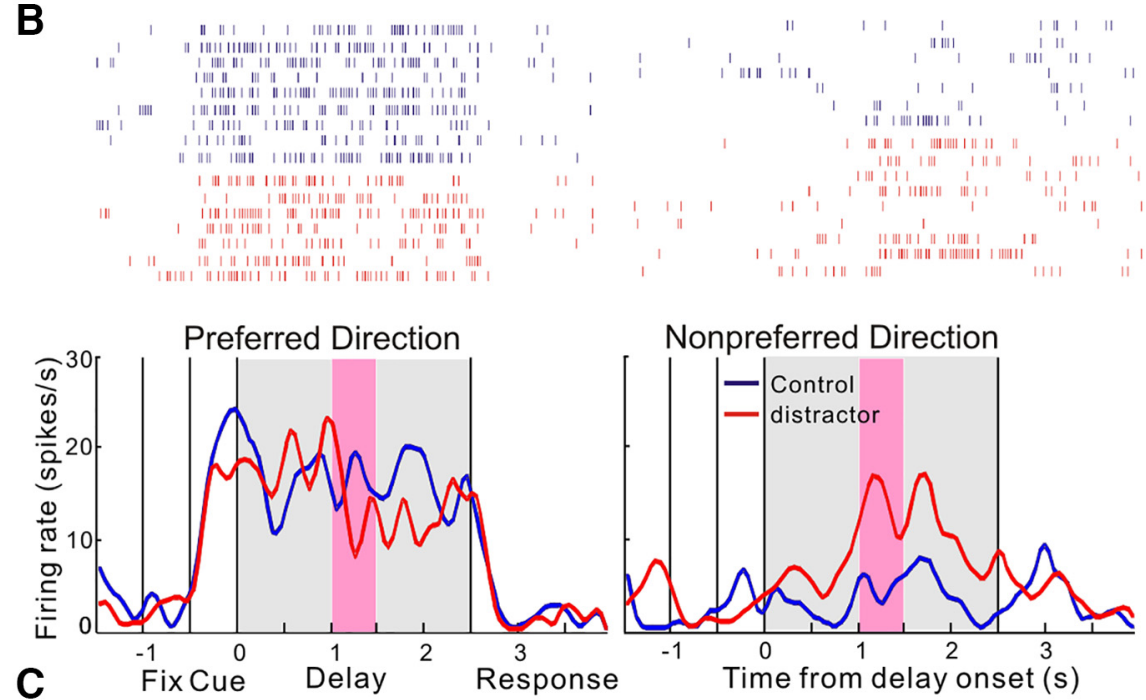

Nonpreferred Direction
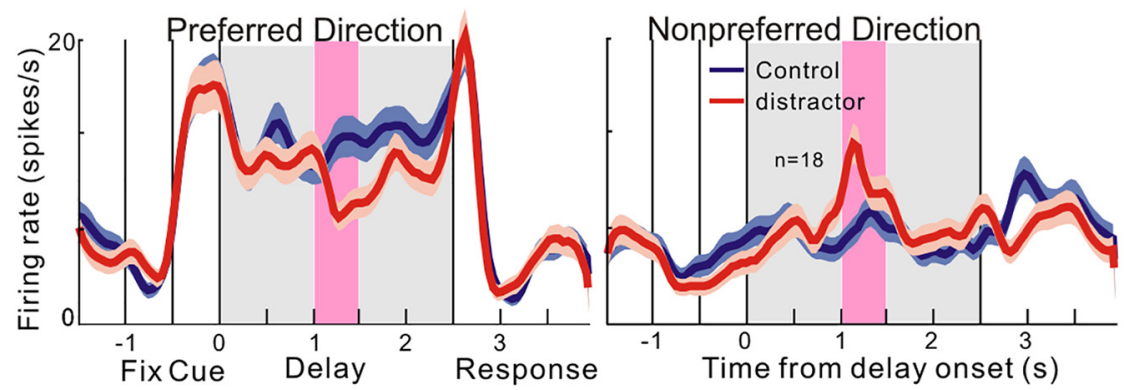

D

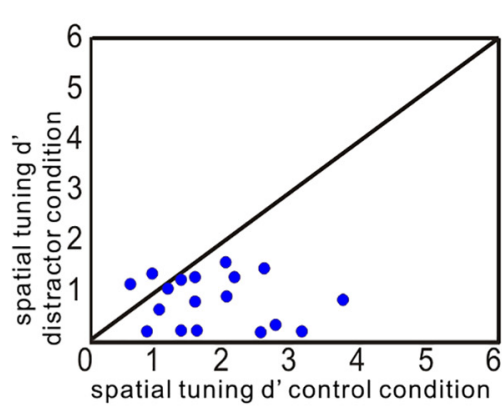

$\mathrm{E}$

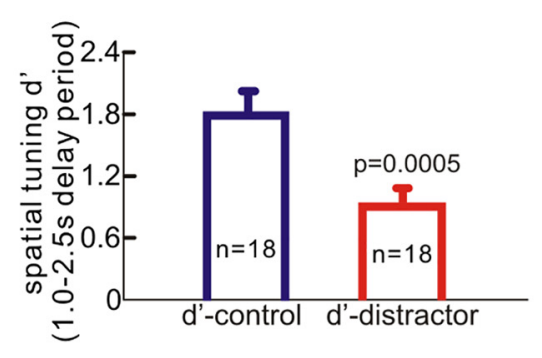

ferred direction was unchanged by drug treatment (distractor vs distractor+RJR2403 condition: $t_{\mathrm{dep}(9)}=1.846, p=0.098$, twotailed paired $t$ test).

A more detailed temporal analysis of neural activity during the delay period can be seen in Figure 5C. Compared with the classic ODR task without distractors, the additions of a distractor significantly reduced neuronal firing during the presentation of the distractor (1-1.5 s period, control vs distractor condition: $t_{\mathrm{dep}(9)}=$ 2.404, $p=0.03$, two-tailed paired $t$ test), as well as the epochs after distractor presentation (1.5-2 s period, control vs distractor condition: $t_{\mathrm{dep}(9)}=2.627, p=$ 0.027, two-tailed paired $t$ test; 2-2.5 s periods, $t_{\mathrm{dep}(9)}=2.439, p=0.037$, twotailed paired $t$ test). Subsequently, iontophoresis of the $\alpha 4 \beta 2-\mathrm{nAChR}$ agonist RJR2403 restored neuronal firing levels during the distractor (1-1.5 s period, distractor vs distractor+RJR2403 condition: $t_{\mathrm{dep}(9)}=2.757, p=0.02$, two-tailed paired $t$ test) and in the time period immediately after distraction (1.5-2 s period, distractor vs distractor + RJR2403 condition: $t_{\mathrm{dep}(9)}=2.991, p=0.02$, twotailed paired $t$ test).

In contrast to the pattern of firing for the neurons' preferred direction, neuronal firing for a neuron's nonpreferred direction significantly increased only during the presentation of the distractor $(1-1.5 \mathrm{~s}$ period, control vs distractor condition: $t_{\mathrm{dep}(9)}=3.919, p=0.003$, two-tailed paired $t$ test), but returned to normal, low levels of firing in the subsequent epochs (1.5-2 period, control vs distractor condition: $t_{\mathrm{dep}(9)}=1.472, p=0.17$, two-tailed paired $t$ test; $2-2.5$ s period, control vs distractor condition: $t_{\mathrm{dep}(9)}=1.957, p=0.08$, two-tailed paired $t$ test). Iontophoresis of an $\alpha 4 \beta 2-\mathrm{nAChR}$ agonist had no effect on neuronal firing for the nonpreferred direction (1-1.5 s period, distractor vs distractor + RJR2403 condition control vs distractor condition: $t_{\mathrm{dep}(9)}=0.3663, p=$ 0.722 , two-tailed paired $t$ test). Overall, stimulation of $\alpha 4 \beta 2-\mathrm{nAChR}$ rescues the loss of delay-related firing caused by distraction, but only by enhancing firing for the neurons' preferred direction.

The next set of experiments examined the effect of $\alpha 4 \beta 2$-nAChR agonists on

$\leftarrow$

Figure 4. Effects of presenting distractors during the delay epoch on working memory performance and dIPFC delay cell firing. $\boldsymbol{A}$, Presentation of distractors significantly impaired the accuracy of spatial working memory performance on the 0DR task. Data are shown as mean \pm SEM. ODR correct rate: $90 \pm 2 \%$; ODR with distractor correct rate: $75 \pm 2 \%$. B. Single-neuron example of the effects of distractor presentation on delay cell firing. Under control conditions (blue), there were no distractors and the neurons showed strong, spatially tuned persistent firing throughout the delay epoch. The presentation of a distractor during the delay period (pink shading) reduced the delay-related firing for the preferred direction and produced the distractor-related activation for the nonpreferred direction (red). C, Consistent effects of distractors on the firing of 18 delay cells. $\boldsymbol{D}$, Scatter plot of $d^{\prime}$ comparing each neuron's firing (1.0-2.5 s of delay period) for its preferred versus nonpreferred directions. $\boldsymbol{E}$, Presentation of the distractor significantly decreased the spatial tuning of delay cell by decreasing the firing for the preferred direction and increasing the firing for the nonpreferred direction. Error bars indicate SEM. 
A

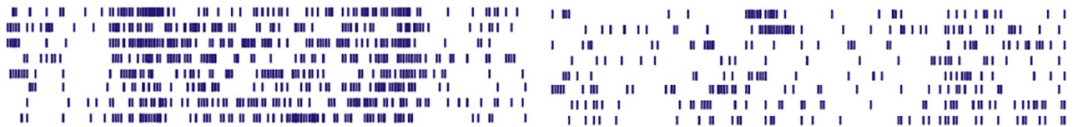

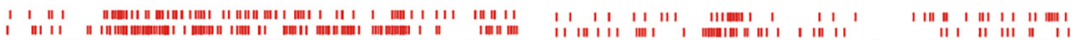

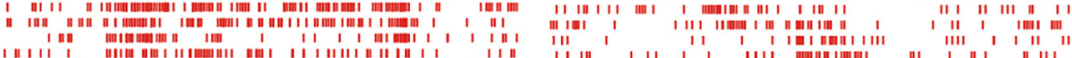

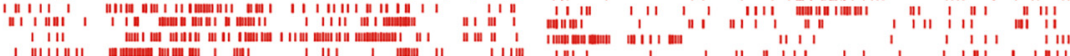

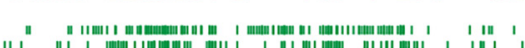

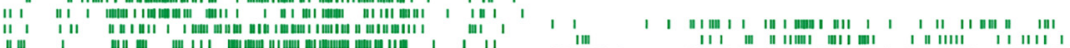

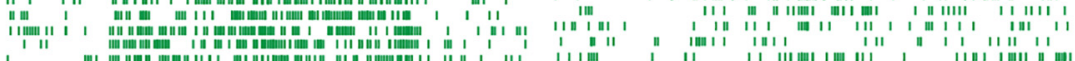

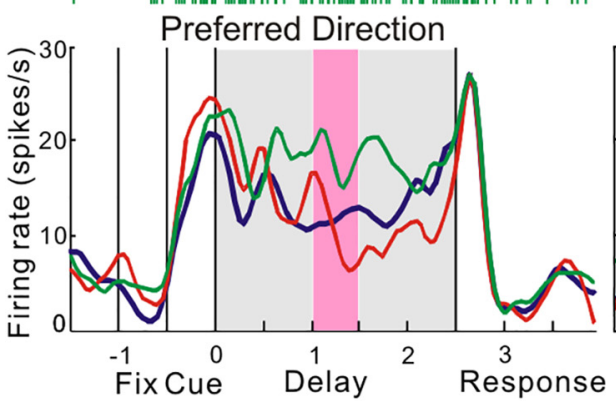

Nonpreferred Direction

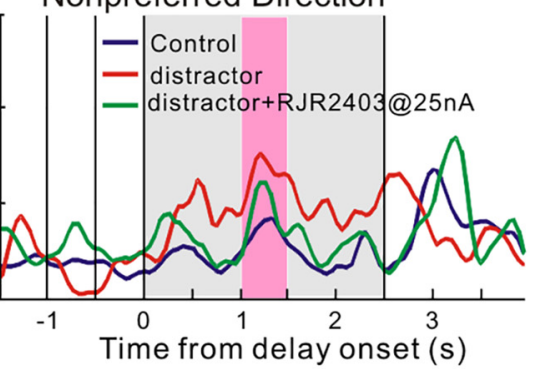

B

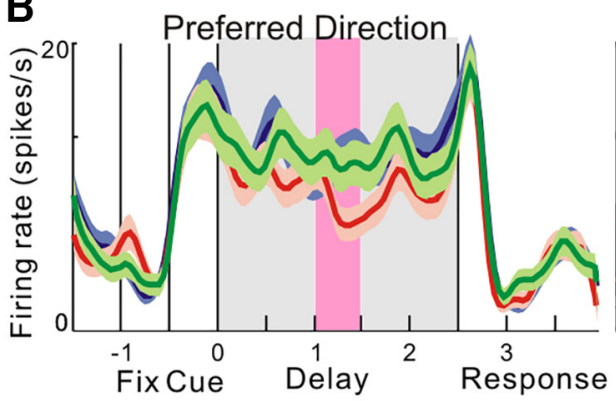

Nonpreferred Direction

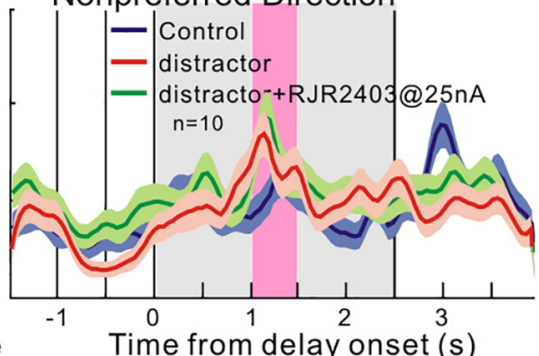

C
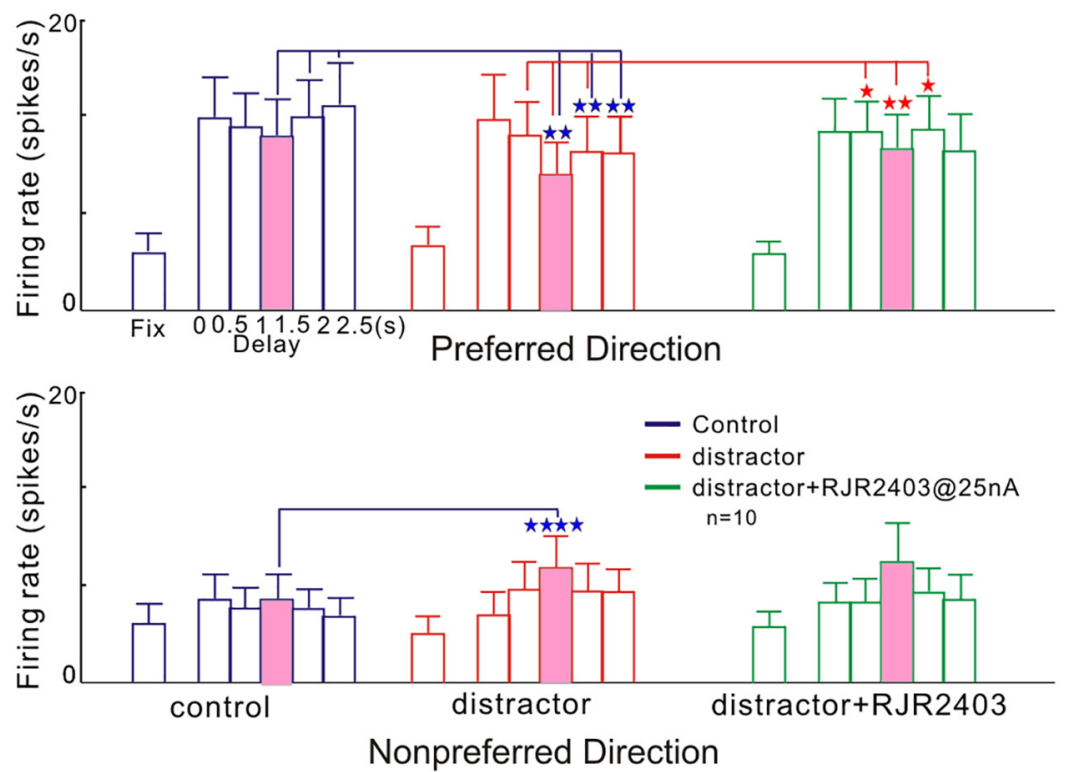

Figure 5. Effects of $\alpha 4 \beta 2-n A C h R$ agonist on the reduced delay-related firing by distractor presentation. $\boldsymbol{A}$, Example of an individual neuron. The presentation of a distractor during the delay period (pink shading) reduced the delay-related firing for the preferred direction (red), and the following iontophoretic application of the $\alpha 4 \beta 2-\mathrm{nAChR}$ agonist RJR2403 significantly restored delay-related activity for the preferred direction (green). B, $\alpha 4 \beta 2-n A C h R$ agonist (green) rescued the reduction of delay-related firing by the distractor presentation (red) at the population level $(n=10)$. C, Detailed analysis of the delay period showing that the distractor reduced the firing significantly during the presentation of the distractor other types of task-related dlPFC neurons: fixation cells, cue cells, and response cells.

\section{Stimulation of $\alpha 4 \beta 2-n A C h R$ enhances the firing of dlPFC fixation cells}

In this experiment, monkeys had to fixate on a central spot of light to initiate a trial and had to maintain fixation throughout the extent of the trial until the fixation point was turned off and the monkey could make a saccadic response to the remembered location for juice reward. Fixation cells in dlPFC initiate firing when the monkey begins fixation regardless of the cue's subsequent spatial position and maintain firing until the fixation point is exterminated (Fig. 6A,B). These cells may be related to the sustained attention and top-down motor control needed to perform the task. Similar to the effect on delay cells, we found that stimulation of the $\alpha 4 \beta 2$-nAChR by ABT-418 or RJR2403 markedly enhanced fixation-related firing. A single neuron example in Figure $6 \mathrm{~A}$ shows that the $\alpha 4 \beta 2$-nAChR agonist RJR2403 produced a dose-related increase in fixation-related firing. Neuronal firing levels returned toward control levels after removal of drug; for example, ABT-418 in Figure $6 B$. These enhancing effects were seen in all fixation cells tested $(n=22)$, with ABT-418 or RJR2403 significantly increasing task-related firing regardless of the spatial position of the cue $\left(t_{\operatorname{dep}(21)}=\right.$ $6.01, p<0.0001$, two-tailed paired $t$ test; Fig. $6 C)$.

\section{Stimulation of $\alpha 4 \beta 2-n A C h R$ has no significant change on the firing of cue cells and response cells}

In contrast to fixation and delay cells, we found that $\alpha 4 \beta 2-\mathrm{nAChR}$ agonists had only subtle effects on the firing of cue or response cells. Given the robust firing of these neurons under control conditions, this may have been due to celling effects. The effects of $\alpha 4 \beta 2-\mathrm{nAChR}$ agonists on the neuronal firing of cue cells are shown in Figure $6 D$ (this cue cell neuron also exhibits response-related firing) and in Figure $6 E$ (averaged response of all cue cells). Application of agonist had no significant change on neuronal firing to the

(1-1.5 $\mathrm{s}$ period) and after the presentation $(1.5-2 \mathrm{~s}$ and $2-2.5 \mathrm{~s}$ period) and $\alpha 4 \beta 2$-nAChR agonist restored the firing significantly during the presentation of the distractor (1-1.5 s period) and after the presentation $(1.5-2 \mathrm{~s})$ for the preferred direction. In contrast, the distractor increased the firing significantly during the presentation of the distractor (1-1.5 s period) for the nonpreferred direction. Error bars indicate SEM. ${ }^{*} p<0.05 ;{ }^{* *} p<0.01 ;{ }^{* * * *} p<0.0001$. 
A

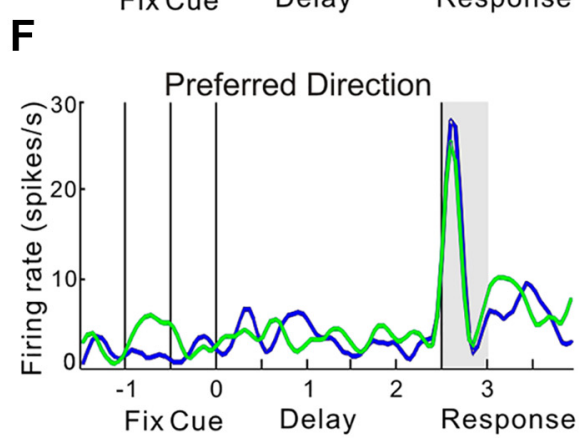

B

D
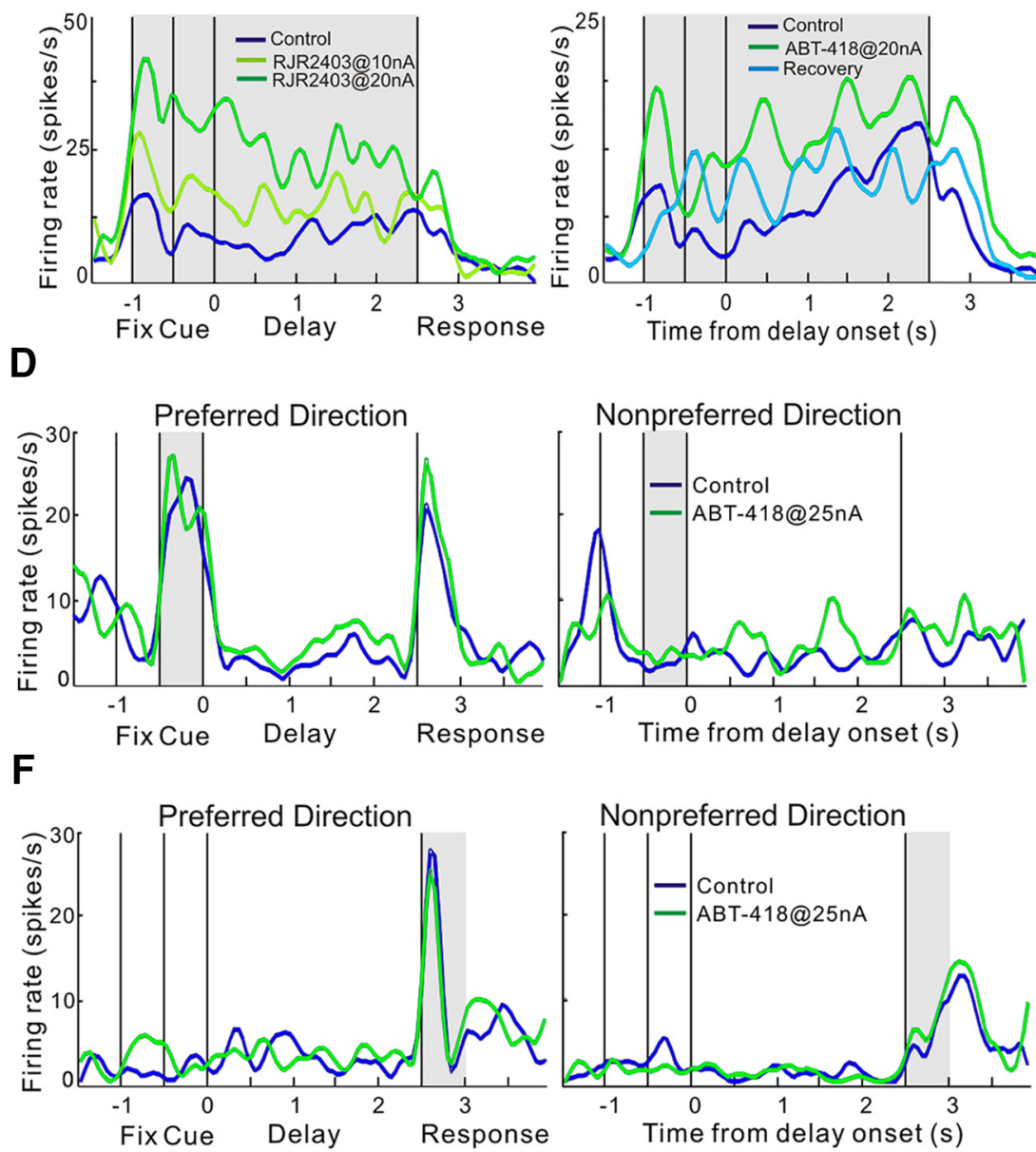

Nonpreferred Direction
C

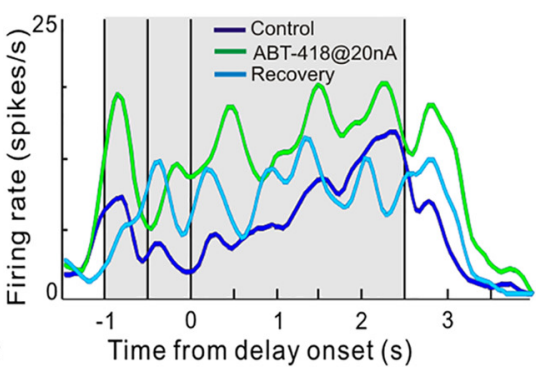

E
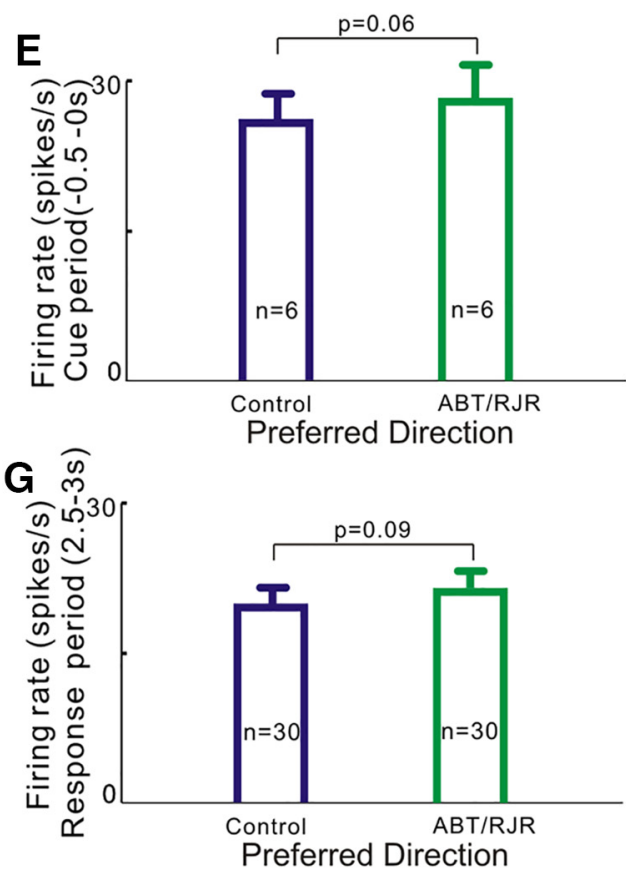

Figure 6. Effects of the $\alpha 4 \beta 2$-nAChR agonists on other task-related neuronal firing. $\boldsymbol{A}$ - $\boldsymbol{C}$, Effects of the $\alpha 4 \beta 2$-nAChR agonists on fixation-related neuronal firing. $\boldsymbol{A}$, Single-neuron example showing that iontophoretic application of RJR2403 significantly enhanced fixation-related activity in the dose-dependent manner. $\boldsymbol{B}$, Single-neuron example showing that the enhancing effects of ABT-418 could be recovered to control levels during the recovery condition (light blue). $C$, Mean \pm SEM firing rate of total 22 fixation cells during fixation-on. $\alpha 4 \beta 2$ agonist significantly enhance the fixation-related firing. $\boldsymbol{D}, \boldsymbol{E}$, Effects of the $\alpha 4 \beta 2$-nAChR agonists on cue-related neuronal firing. Both a single-neuron example and population data show that $\alpha 4 \beta 2$ agonists have no significant change on the cue-related firing for the preferred direction. $\boldsymbol{F}, \mathbf{G}$, Effects of the $\alpha 4 \beta 2$-nAChR agonists on response-related neuronal firing. Both a single-neuron example and population data show that $\alpha 4 \beta 2$ agonists have no significant change on the response-related firing for the preferred direction. Error bars indicate SEM.

cue for the neurons' preferred direction $\left(t_{\mathrm{dep}(5)}=2.407, p=0.06\right.$, two-tailed paired $t$ test; Fig. $6 E$ ). Similarly, $\alpha 4 \beta 2$ agonists had no significant effect on response-related firing $\left(t_{\operatorname{dep}(29)}=1.757, p=\right.$ 0.09 , two-tailed paired $t$ test; Fig. $6 F, G)$. Therefore, $\alpha 4 \beta 2$ $\mathrm{nAChR}$ stimulation enhanced the firing of delay and fixation cells in the dlPFC, but had little effect on cue and response cells.

\section{Discussion}

This is the first study of $\alpha 4 \beta 2-n A C h R$ influences on dlPFC neuronal physiology in primates, including the very first study of modulatory influences on dlPFC fixation cells. The data showed that iontophoretic stimulation of $\alpha 4 \beta 2$-nAChR in monkey dlPFC enhanced the task-related firing of both fixation and delay cells, with delay cells showing improved spatial tuning and stronger resistance to distractors after $\alpha 4 \beta 2$-nAChR agonist application. These data are consistent with a larger literature indicating a role of $\alpha 4 \beta 2-n A C h R$ in working memory and attentional control. In addition, the study also revealed an unexpected dissociation in neuronal response, where $\alpha 4 \beta 2-\mathrm{nAChR}$ agonists rescued delay cell firing during distraction for the neurons' preferred direction, but not for the nonpreferred direction. These data suggest unknown dlPFC circuit mechanisms when the initial cue and the distractors are in similar locations. Despite this unexpected response, the overall $d^{\prime}$ was improved by $\alpha 4 \beta 2$-nAChR agonist stimulation during distracting conditions, indicating a beneficial role in top-down attention.

\section{Importance of $\alpha 4 \beta 2-\mathrm{nAChR}$ mechanisms to cognitive circuits}

Ach plays a widespread role in coordinating arousal with cognitive state. For example, Ach in the rodent medial PFC has been shown to regulate Ach release in posterior cortex (Nelson et al., 2005), consistent with a cholinergic orchestration of attentional and executive circuits (Hasselmo and Sarter, 2011). Ach actions at $\alpha 4 \beta 2-\mathrm{nAChR}$ likely contribute to this arrangement because mice lacking $\beta 2-n A C h R$ subunits have impaired attention (Guillem et al., 2011). Conversely, mice administered the $\alpha 4 \beta 2$-nAChR agonist ABT-418 showed improvement in a test of sustained attention (Young et al., 2013). Similarly, monkeys administered ABT-418 showed improvement in a working memory task, particularly under conditions of distraction (Prendergast et al., 1998).

Genetic variations in the $\alpha 4$ subunit in human subjects have been related to a variety of differences in cognitive operations 
thought to be mediated by the PFC. For example, performance of the Stroop interference and Trails B tasks are related to $\alpha 4$ genotype and these tasks both depend on PFC function and require suppression of distraction and inhibition of a prepotent response (Reinvang et al., 2009). The $\alpha 4$ genotype interacts with the dopamine D2 receptor genotype in mediating nicotine's effects on performance of an attention task with distracters (Ahrens et al., 2015). Similarly, the genotype for the noradrenergic synthetic enzyme dopamine $\beta$ hydroxylase interacts with the $\alpha 4$ genotype in relationship to working memory abilities with varying attentional load (Greenwood et al., 2009). The $\alpha 4$ genotype has also been related to activity of the anterior cingulate and posterior parietal cortex during an oddball task (Winterer et al., 2007) and to alterations in posterior attentional circuits in tasks that require the reorienting of attention (Giessing et al., 2012; Greenwood et al., 2012). Because $\alpha 4 \beta 2-\mathrm{nAChR}$ expression is widespread in the brain, these relationships likely involve receptors in multiple brain circuits. However, the current data suggest that genetic differences in $\alpha 4 \beta 2$-nAChR within dlPFC may contribute to variations in cognitive and attentional abilities in human subjects.

\section{Speculations on cellular mechanisms within dlPFC}

Single-unit recordings in awake, behaving monkeys do not allow identification of the neuronal cell type or laminar location of the neuron under study, but previous studies by Goldman-Rakic and colleagues strongly suggest that delay cells likely reside in deep layer III of dlPFC. Delay cell firing arises from the recurrent excitation of pyramidal cell microcircuits that excite each other via NMDAR on spines to maintain persistent firing across the delay period in the absence of sensory stimulation (Goldman-Rakic, 1995; Wang et al., 2013; Riley and Constantinidis, 2015). In contrast, the spatial tuning of delay cells arises from lateral inhibition from fast-spiking GABAergic interneurons (Goldman-Rakic, 1995; Rao et al., 2000). Although superficial layer V shows some evidence of extended horizontal projections, these are not as extensive as layer III (Kritzer and Goldman-Rakic, 1995). In contrast, the laminar identity of fixation cells is unknown. There is also no knowledge of the ultrastructural localization of $\alpha 4 \beta 2$ $\mathrm{nAChR}$ in the primate dlPFC, which hampers hypotheses regarding cellular mechanisms. Studies from rodent medial PFC suggest that $\beta 2$-subunit-containing receptors reside on both non-fastspiking interneurons and layer VI pyramidal cells (Bloem et al., 2014), as well as on presynaptic thalamocortical terminals, where they increase glutamate release (Lambe et al., 2003). Given the great evolutionary expansion of layer III dlPFC in primates (Elston, 2003; Defelipe, 2011), there are likely to be species differences in some of these mechanisms. However, $\alpha 4 \beta 2$-nAChR influences on catecholamine release in cortex may be shared across species. In rat PFC, stimulation of $\beta 2$-containing $\mathrm{nAChR}$ can increase release of norepinephrine (NE) (Kennett et al., 2012) or dopamine (Livingstone et al., 2009). If the same is true in primate dlPFC, then some of the excitatory effects of $\alpha 4 \beta 2$ nAChR stimulation could arise through these mechanisms. For example, NE can increase the firing of dlPFC delay cells through stimulation of postsynaptic $\alpha 2 \mathrm{~A}$-adrenoceptors on layer III dendritic spines, which inhibit cAMP-PKA-K ${ }^{+}$channel signaling (Wang et al., 2007; Wang et al., 2011). Low levels of dopamine release could also increase delay cell firing through D1R phosphorylation of NMDAR, although this mechanism in primates is currently only speculative (Arnsten et al., 2015). Therefore, catecholamine actions, as well as increases in glutamate release and direct postsynaptic action, may all contribute to $\alpha 4 \beta 2$-nAChR's enhancing effects on delay cell firing. Mechanisms underlying the enhancing effects on fixation cells are unknown because there has been so little previous research on these neurons.

\section{Clinical relevance}

Understanding $\alpha 4 \beta 2$-nAChR actions may also be relevant to the etiology and treatment of ADHD (Wilens and Decker, 2007). There is extensive evidence that ADHD involves dysfunction and slowed and/or impaired maturation of the PFC (Rubia et al., 1999; Shaw et al., 2009; Arnsten and Rubia, 2012; Shaw et al., 2013). There are also potential links between the incidence of $\mathrm{ADHD}$ symptoms and alterations in the $\alpha 4 \mathrm{nAChR}$ genotype, although data have been mixed (Kent et al., 2001; Lee et al., 2008). $\alpha 4 \beta 2-\mathrm{nAChR}$ agonists have been considered as potential therapies for ADHD patients (Wilens and Decker, 2007), although there are concerns about possible addictive potential (Henningfield and Zeller, 2009; Picciotto and Kenny, 2013). An initial pilot study of ABT-418 in adults with ADHD showed subtle improvement with an inverted U dose-response (Wilens et al., 1999). Although further studies of a partial $\alpha 4 \beta 2$-nAChR agonist, ABT089, had no effects in children (Wilens et al., 2011; Childress and Sallee, 2014) or adults (Bain et al., 2012) with ADHD, preliminary results with a more selective $\alpha 4 \beta 2$-nAChR agonist, ABT894, are promising (Bain et al., 2013). The current data, showing that $\alpha 4 \beta 2-\mathrm{nAChR}$ stimulation enhances dlPFC neuronal activity needed to sustain goals in the presence of distraction, suggest that stronger PFC function may contribute to potential therapeutic actions.

\section{References}

Ahrens S, Markett S, Breckel TP, Behler O, Reuter M, Thiel CM (2015) Modulation of nicotine effects on selective attention by DRD2 and CHRNA4 gene polymorphisms. Psychopharmacology 232:2323-2331. CrossRef Medline

Arnsten AF, Rubia K (2012) Neurobiological circuits regulating attention, cognitive control, motivation, and emotion: disruptions in neurodevelopmental psychiatric disorders. J Am Acad Child Adolesc Psychiatry 51: 356-367. CrossRef Medline

Arnsten AF, Wang M, Paspalas CD (2015) Dopamine's actions in primate prefrontal cortex: challenges for treating cognitive disorders. Pharmacol Rev 67:681-696. CrossRef Medline

Bain EE, Apostol G, Sangal RB, Robieson WZ, McNeill DL, Abi-Saab WM, Saltarelli MD (2012) A randomized pilot study of the efficacy and safety of ABT-089, a novel $\alpha 4 \beta 2$ neuronal nicotinic receptor agonist, in adults with attention-deficit/hyperactivity disorder. J Clin Psychiatry 73:783789. CrossRef Medline

Bain EE, Robieson W, Pritchett Y, Garimella T, Abi-Saab W, Apostol G, McGough JJ, Saltarelli MD (2013) A randomized, double-blind, placebo-controlled phase 2 study of $\alpha 4 \beta 2$ agonist ABT- 894 in adults with ADHD. Neuropsychopharmacology 38:405-413. CrossRef Medline

Bartus RT, Johnson HR (1976) Short-term memory in the rhesus monkey: disruption from the anti-cholinergic scopolamine. Pharmacol Biochem Behav 5:39-46. CrossRef Medline

Bartus RT, Levere TE (1977) Frontal decortication in rhesus monkeys: a test of the interference hypothesis. Brain Res 119:233-248. CrossRef Medline

Bloem B, Poorthuis RB, Mansvelder HD (2014) Cholinergic modulation of the medial prefrontal cortex: the role of nicotinic receptors in attention and regulation of neuronal activity. Front Neural Circuits 8:17. CrossRef Medline

Buschman TJ, Miller EK (2007) Top-down versus bottom-up control of attention in the prefrontal and posterior parietal cortices. Science 315: 1860-1862. CrossRef Medline

Childress A, Sallee FR (2014) Pozanicline for the treatment of attentiondeficit/hyperactivity disorder. Expert Opin Investig Drugs 23:1585-1593. CrossRef Medline

Croxson PL, Kyriazis DA, Baxter MG (2011) Cholinergic modulation of a specific memory function of prefrontal cortex. Nat Neurosci 14:1510 1512. CrossRef Medline

Defelipe J (2011) The evolution of the brain, the human nature of cortical circuits, and intellectual creativity. Front Neuroanat 5:29. CrossRef Medline 
Disney AA, Aoki C, Hawken MJ (2007) Gain modulation by nicotine in macaque v1. Neuron 56:701-713. CrossRef Medline

Elston GN (2003) Cortex, cognition and the cell: new insights into the pyramidal neuron and prefrontal function. Cereb Cortex 13:1124-1138. CrossRef Medline

Espeseth T, Sneve MH, Rootwelt H, Laeng B (2010) Nicotinic receptor gene CHRNA4 interacts with processing load in attention. PLoS One 5:e14407. CrossRef Medline

Funahashi S, Bruce CJ, Goldman-Rakic PS (1991) Neuronal activity related to saccadic eye movements in the monkey's dorsolateral prefrontal cortex. J Neurophysiol 65:1464-1483. Medline

Giessing C, Neber T, Thiel CM (2012) Genetic variation in nicotinic receptors affects brain networks involved in reorienting attention. Neuroimage 59:831-839. CrossRef Medline

Goard M, Dan Y (2009) Basal forebrain activation enhances cortical coding of natural scenes. Nat Neurosci 12:1444-1449. CrossRef Medline

Goldman-Rakic PS (1995) Cellular basis of working memory. Neuron 14: 477-485. CrossRef Medline

Granon S, Poucet B, Thinus-Blanc C, Changeux JP, Vidal C (1995) Nicotinic and muscarinic receptors in the rat prefrontal cortex: differential roles in working memory, response selection and effortful processing. Psychopharmacology 119:139-144. CrossRef Medline

Greenwood PM, Sundararajan R, Lin MK, Kumar R, Fryxell KJ, Parasuraman R (2009) Both a nicotinic single nucleotide polymorphism (SNP) and a noradrenergic SNP modulate working memory performance when attention is manipulated. J Cogn Neurosci 21:2139-2153. CrossRef Medline

Greenwood PM, Parasuraman R, Espeseth T (2012) A cognitive phenotype for a polymorphism in the nicotinic receptor gene CHRNA4. Neurosci Biobehav Rev 36:1331-1341. CrossRef Medline

Grueninger WE, Pribram KH (1969) Effects of spatial and nonspatial distractors on performance latency of monkeys with frontal lesions. J Comp Physiol Psychol 68:203-209. CrossRef Medline

Guillem K, Bloem B, Poorthuis RB, Loos M, Smit AB, Maskos U, Spijker S, Mansvelder HD (2011) Nicotinic acetylcholine receptor $\beta 2$ subunits in the medial prefrontal cortex control attention. Science 333:888-891. CrossRef Medline

Han ZY, Le Novère N, Zoli M, Hill JA Jr, Champtiaux N, Changeux JP (2000) Localization of nAChR subunit mRNAs in the brain of Macaca mulatta. Eur J Neurosci 12:3664-3674. CrossRef Medline

Hasselmo ME, Sarter M (2011) Modes and models of forebrain cholinergic neuromodulation of cognition. Neuropsychopharmacology 36:52-73. CrossRef Medline

Henningfield JE, Zeller M (2009) Nicotine psychopharmacology: policy and regulatory. Handb Exp Pharmacol 192:511-534. CrossRef Medline

Herrero JL, Roberts MJ, Delicato LS, Gieselmann MA, Dayan P, Thiele A (2008) Acetylcholine contributes through muscarinic receptors to attentional modulation in V1. Nature 454:1110-1114. CrossRef Medline

Keedy SK, Ebens CL, Keshavan MS, Sweeney JA (2006) Functional magnetic resonance imaging studies of eye movements in first episode schizophrenia: smooth pursuit, visually guided saccades and the oculomotor delayed response task. Psychiatry Res 146:199-211. CrossRef Medline

Kennett A, Heal DJ, Wonnacott S (2012) Pharmacological differences between rat frontal cortex and hippocampus in the nicotinic modulation of noradrenaline release implicate distinct receptor subtypes. Nicotine Tob Res 14:1339-1345. CrossRef Medline

Kent L, Middle F, Hawi Z, Fitzgerald M, Gill M, Feehan C, Craddock N (2001) Nicotinic acetylcholine receptor alpha4 subunit gene polymorphism and attention deficit hyperactivity disorder. Psychiatr Genet 11: 37-40. CrossRef Medline

Kritzer MF, Goldman-Rakic PS (1995) Intrinsic circuit organization of the major layers and sublayers of the dorsolateral prefrontal cortex in the rhesus monkey. J Comp Neurol 359:131-143. CrossRef Medline

Lambe EK, Picciotto MR, Aghajanian GK (2003) Nicotine induces glutamate release from thalamocortical terminals in prefrontal cortex. Neuropsychopharmacology 28:216-225. CrossRef Medline

Lee J, Laurin N, Crosbie J, Ickowicz A, Pathare T, Malone M, Kennedy JL, Tannock R, Schachar R, Barr CL (2008) Association study of the nicotinic acetylcholine receptor alpha4 subunit gene, CHRNA4, in attentiondeficit hyperactivity disorder. Genes Brain Behav 7:53-60. Medline

Levin ED, McClernon FJ, Rezvani AH (2006) Nicotinic effects on cognitive function: behavioral characterization, pharmacological specification, and anatomic localization. Psychopharmacology 184:523-539. CrossRef Medline

Livingstone PD, Srinivasan J, Kew JN, Dawson LA, Gotti C, Moretti M, Shoaib M, Wonnacott S (2009) alpha7 and non-alpha7 nicotinic acetylcholine receptors modulate dopamine release in vitro and in vivo in the rat prefrontal cortex. Eur J Neurosci 29:539-550. CrossRef Medline

Mansvelder HD, Mertz M, Role LW (2009) Nicotinic modulation of synaptic transmission and plasticity in cortico-limbic circuits. Semin Cell Dev Biol 20:432-440. CrossRef Medline

McClure-Begley TD, Esterlis I, Stone KL, Lam TT, Grady SR, Colangelo CM, Lindstrom JM, M.J. M, Picciotto MR (2016) Evaluation of the nicotinic acetylcholine receptor-associated proteome at baseline and following nicotine exposure in human and mouse cortex: $\mathrm{nAChR}$-associated proteome in mouse and human cortex eNeuro 3. CrossRef Medline

Miller EK, Erickson CA, Desimone R (1996) Neural mechanisms of visual working memory in prefrontal cortex of the macaque. J Neurosci 16:51545167. Medline

Mobascher A, Diaz-Lacava A, Wagner M, Gallinat J, Wienker TF, Drichel D, Becker T, Steffens M, Dahmen N, Gründer G, Thürauf N, Kiefer F, Kornhuber J, Toliat MR, Thiele H, Nürnberg P, Steinlein O, Winterer G (2016) Association of common polymorphisms in the nicotinic acetylcholine receptor alpha4 subunit gene with an electrophysiological endophenotype in a large population-based sample. PLoS One 11:e0152984. CrossRef Medline

Nelson CL, Sarter M, Bruno JP (2005) Prefrontal cortical modulation of acetylcholine release in posterior parietal cortex. Neuroscience 132:347359. CrossRef Medline

Picciotto MR, Kenny PJ (2013) Molecular mechanisms underlying behaviors related to nicotine addiction. Cold Spring Harb Perspect Med 3:a012112. CrossRef Medline

Prendergast MA, Jackson WJ, Terry AVJ, Decker MW, Arneric SP, Buccafusco JJ (1998) Central nicotinic receptor agonists ABT-418, ABT-089, and (-)-nicotine reduce distractibility in adult monkeys. Psychopharmacology (Berl) 136:50-58. CrossRef

Rao SG, Williams GV, Goldman-Rakic PS (2000) Destruction and creation of spatial tuning by disinhibition: GABA(A) blockade of prefrontal cortical neurons engaged by working memory. J Neurosci 20:485-494. Medline

Reinvang I, Lundervold AJ, Rootwelt H, Wehling E, Espeseth T (2009) Individual variation in a cholinergic receptor gene modulates attention. Neurosci Lett 453:131-134. CrossRef Medline

Riley MR, Constantinidis C (2015) Role of prefrontal persistent activity in working memory. Front Syst Neurosci 9:181. CrossRef Medline

Rossi AF, Bichot NP, Desimone R, Ungerleider LG (2007) Top-down attentional deficits in macaques with lesions of lateral prefrontal Cortex. J Neurosci 27:11306-11314. CrossRef Medline

Rubia K, Overmeyer S, Taylor E, Brammer M, Williams SC, Simmons A, Bullmore ET (1999) Hypofrontality in Attention Deficit Hyperactivity Disorder during higher-order motor control: a study with functional MRI. Am J Psychiatry 156:891-896. CrossRef Medline

Sarter M, Bruno JP, Himmelheber AM (1997) Cortical acetylcholine and attention: Principles directing treatment strategies for cognitive disorders. In: Pharmacological treatment of Alzheimer's disease: molecular and neurobiological foundations (Brioni JD, Decker MW, eds), pp 105128. New York: Wiley.

Shaw P, Lalonde F, Lepage C, Rabin C, Eckstrand K, Sharp W, Greenstein D, Evans A, Giedd JN, Rapoport J (2009) Development of cortical asymmetry in typically developing children and its disruption in attention-deficit/ hyperactivity disorder. Arch Gen Psychiatry 66:888-896. CrossRef Medline

Shaw P, Malek M, Watson B, Greenstein D, de Rossi P, Sharp W (2013) Trajectories of cerebral cortical development in childhood and adolescence and adult attention-deficit/hyperactivity disorder. Biol Psychiatry 74:599-606. CrossRef Medline

Suzuki M, Gottlieb J (2013) Distinct neural mechanisms of distractor suppression in the frontal and parietal lobe. Nat Neurosci 16:98-104. CrossRef Medline

Vijayraghavan S, Wang M, Birnbaum SG, Bruce CJ, Williams GV, Arnsten AF (2007) Inverted-U dopamine D1 receptor actions on prefrontal neurons engaged in working memory. Nat Neurosci 10:376-384. CrossRef Medline

Wallis D, Arcos-Burgos M, Jain M, Castellanos FX, Palacio JD, Pineda D, Lopera F, Stanescu H, Pineda D, Berg K, Palacio LG, Bailey-Wilson JE, Muenke M (2009) Polymorphisms in the neural nicotinic acetylcholine 
receptor $\alpha 4$ subunit (CHRNA4) are associated with ADHD in a genetic isolate. Atten Defic Hyperact Disord 1:19-24. CrossRef Medline

Wang M, Ramos BP, Paspalas CD, Shu Y, Simen A, Duque A, Vijayraghavan S, Brennan A, Dudley A, Nou E, Mazer JA, McCormick DA, Arnsten AF (2007) Alpha2A-adrenoceptor stimulation strengthens working memory networks by inhibiting cAMP-HCN channel signaling in prefrontal cortex. Cell 129:397-410. CrossRef Medline

Wang M, Gamo NJ, Yang Y, Jin LE, Wang XJ, Laubach M, Mazer JA, Lee D, Arnsten AF (2011) Neuronal basis of age-related working memory decline. Nature 476:210-213. CrossRef Medline

Wang M, Yang Y, Wang CJ, Gamo NJ, Jin LE, Mazer JA, Morrison JH, Wang XJ, Arnsten AF (2013) NMDA receptors subserve working memory persistent neuronal firing In dorsolateral prefrontal cortex. Neuron 77:736749. CrossRef Medline

Wilens TE, Decker MW (2007) Neuronal nicotinic receptor agonists for the treatment of attention-deficit/hyperactivity disorder: focus on cognition. Biochem Pharmacol 74:1212-1223. CrossRef Medline

Wilens TE, Biederman J, Spencer TJ, Bostic J, Prince J, Monuteaux MC, Soriano J, Fine C, Abrams A, Rater M, Polisner D (1999) A pilot controlled clinical trial of ABT-418, a cholinergic agonist, in the treatment of adults with attention deficit hyperactivity disorder. Am J Psychiatry 156: 1931-1937. Medline
Wilens TE, Gault LM, Childress A, Kratochvil CJ, Bensman L, Hall CM, Olson E, Robieson WZ, Garimella TS, Abi-Saab WM, Apostol G, Saltarelli MD (2011) Safety and efficacy of ABT-089 in pediatric attention-deficit/hyperactivity disorder: Results from two randomized placebo-controlled clinical trials. J Am Acad Child Adolesc Psychiatry 50:73-84.e1. CrossRef Medline

Winterer G, Musso F, Konrad A, Vucurevic G, Stoeter P, Sander T, Gallinat J (2007) Association of attentional network function with exon 5 variations of the CHRNA4 gene. Hum Mol Genet 16:2165-2174. CrossRef Medline

Wood C, Kohli S, Malcolm E, Allison C, Shoaib M (2016) Subtype-selective nicotinic acetylcholine receptor agonists can improve cognitive flexibility in an attentional set shifting task. Neuropharmacology 105:106-113. CrossRef Medline

Yang Y, Paspalas CD, Jin LE, Picciotto MR, Arnsten AF, Wang M (2013) Nicotinic $\alpha 7$ receptor enhance NMDA cognitive circuits in dorsolateral prefrontal cortex. Proc Natl Acad Sci U S A 110:12078-12083. CrossRef Medline

Young JW, Meves JM, Geyer MA (2013) Nicotinic agonist-induced improvement of vigilance in mice in the 5-choice continuous performance test. Behav Brain Res 240:119-133. CrossRef Medline 